OPEN ACCESS

Edited by:

Chaofeng Han,

Second Military Medical University,

China

Reviewed by:

Stefania Raimondo,

University of Palermo, Italy

Lei Shi,

Georgia State University,

United States

Zhanli Wang,

Baotou Medical College, China

${ }^{*}$ Correspondence:

Yanmei Zhao

zhaoyanmei@126.com

Qiang Yang

yangqiang1980@126.com

Yanhong Zhao

leafzh@126.com

Specialty section:

This article was submitted to Molecular Innate Immunity,

a section of the journal

Frontiers in Immunology

Received: 04 October 2021 Accepted: 22 November 2021 Published: 16 December 2021

Citation:

Xing $Y$, Sun $X$, Dou $Y$,

Wang $M$, Zhao $Y$, Yang $Q$ and

Zhao $Y$ (2021) The Immuno-

Modulation Effect of Macrophage-

Derived Extracellular Vesicles in

Chronic Inflammatory Diseases.

Front. Immunol. 12:785728.

doi: 10.3389/fimmu.2021.785728

\section{The Immuno-Modulation Effect of Macrophage-Derived Extracellular Vesicles in Chronic Inflammatory Diseases}

\author{
Yi Xing ${ }^{1}$, Xun Sun ${ }^{2}$, Yiming Dou ${ }^{2}$, Min Wang ${ }^{1}$, Yanmei Zhao ${ }^{3 *}$, Qiang Yang ${ }^{2 *}$ \\ and Yanhong Zhao ${ }^{1 *}$ \\ 1 Department of Orthodontics, Hospital of Stomatology, Tianjin Medical University, Tianjin, China, ${ }^{2}$ Department of Spine \\ Surgery, Tianjin Hospital, Tianjin University, Tianjin, China, ${ }^{3}$ Institute of Disaster and Emergency Medicine, Tianjin University, \\ Tianjin, China
}

As natural nanocarriers and intercellular messengers, extracellular vesicles (EVs) control communication among cells. Under physiological and pathological conditions, EVs deliver generic information including proteins and nucleic acids to recipient cells and exert regulatory effects. Macrophages help mediate immune responses, and macrophagederived EVs may play immunomodulatory roles in the progression of chronic inflammatory diseases. Furthermore, EVs derived from various macrophage phenotypes have different biological functions. In this review, we describe the pathophysiological significance of macrophage-derived extracellular vesicles in the development of chronic inflammatory diseases, including diabetes, cancer, cardiovascular disease, pulmonary disease, and gastrointestinal disease, and the potential applications of these EVs.

Keywords: macrophage-derived extracellular vesicles, immunomodulation, chronic diseases, therapeutic strategy, inflammation

\section{BACKGROUND}

Extracellular vesicles (EVs) are natural phospholipid bilayer-derived particles expressing specific surface markers (e.g., tetraspanins, Alix, and TSG101) secreted by cells into the extracellular space (1). EVs have been isolated from various types of cells, tissues, and even bodily fluids (2). They are categorized mainly as exosomes ( $\sim 40-160 \mathrm{~nm}$ diameter), microvesicles, and apoptotic bodies ( $\sim 50$ $\mathrm{nm}$ to $1 \mu \mathrm{m}$ diameter) $(3,4)$. Initially, EVs were considered waste released by cells $(5)$. More recently, their roles in cell-cell interactions have been identified $(6,7)$. Various cargos in the form of nucleic acids, proteins, lipids, and metabolites are transferred by EVs to recipient cells, thereby influencing the biological functions of those cells. EVs are highly heterogeneous and dynamic, depending on the parental cell source and microenvironment (3). Due to their unique characteristics and properties, EVs are critical mediators of various physiological and pathological processes including the immune response, cell proliferation and migration, tumor invasion, and metastasis (8-10). Furthermore, they are used as diagnostic tools and as therapeutic delivery systems carrying biological factors and/or drugs (11-13). 
Macrophages $(\mathrm{M} \varphi)$ are derived from monocytes in the bone marrow and are involved in specific and nonspecific immunity of the body. In nonspecific immunity, the biological functions of $\mathrm{M} \varphi$ include removing dead cells and cellular debris, and presenting antigens for recognition. In specific immunity, activated $\mathrm{M} \varphi$ have immunomodulatory functions by secreting cytokines. Moreover, they play a major role in antigen presentation and initiation of the immune response (14). M $\varphi$ are divided mainly into two phenotypes: classically activated M1 $(\mathrm{M} 1 \mathrm{M} \varphi)$ and alternatively activated $\mathrm{M} 2(\mathrm{M} 2 \mathrm{M} \varphi)(15) . \mathrm{M} \varphi$ play essential roles in the microenvironment and are also regulated by that microenvironment. Phenotypic polarization of $\mathrm{M} \varphi$ has a dynamic influence on the balance between inflammation and tissue repair. Moreover, the functions and properties of EVs secreted from $\mathrm{M} \varphi(\mathrm{M} \varphi$-EVs) are influenced by $\mathrm{M} \varphi$ polarization, with different phenotypes of $\mathrm{M} \varphi$-EVs being involved in diverse biological processes under various physiological and pathological conditions (16).

Inflammation is defined biologically as the response of the body's immune system to a stimulus. Mainly caused by various pathogens and tissue damage, it plays an important role in tissue repair and is considered a protective response of the organism (17). Activated $M \varphi$ dominate the histopathology of chronic inflammation and can amplify the inflammatory response by mediating the release of inflammatory mediators (18). In 2010, the WHO stated that chronic diseases such as cardiovascular disease, diabetes, cancer, and chronic respiratory disease account for approximately two-thirds of global deaths (19). To date, several studies have confirmed the link between chronic inflammation and chronic disease, although the exact mechanisms are still not clear (20-22). Inflammation not only plays an important role in host defense mechanisms but also greatly contributes to the pathological process of chronic diseases. Therefore, targeting inflammation is a promising strategy for improving and treating chronic diseases.

In this review, we summarize the crucial role of $\mathrm{M} \varphi$-EVs in the pathogenic mechanisms of chronic diseases such as atherosclerosis, diabetes, cancer, lung-related disease, cardiovascular-related disease, and gastrointestinal-related disease. In addition, therapeutic strategies based on $\mathrm{M} \varphi$-EVs are discussed, as well as the challenges associated with their application.

\section{$M \varphi-E V s$}

EVs are vesicles derived from the phospholipid bilayer released by cells (23), including various subtypes of nanoscale-tomicroscale particles. They transmit information that helps regulate recipient cells (Table 1). Furthermore, they retain the biological properties of the parental cells (71). Thus, different phenotypes of $\mathrm{M} \varphi$-EVs play different roles in different pathological conditions (Figure 1).

However, there is no consensus on the specific markers of EVs subtypes according to the MISEV2018 (23). In this review, we primarily focus on EVs $150 \mathrm{~nm}$ or less in size.

\section{Molecular Components of $\mathrm{M} \varphi-\mathrm{EVs}$}

The RNA molecules enclosed in $\mathrm{M} \varphi$-EVs comprise mainly mRNA (intact mRNA and mRNA fragments) $(31,43)$, miRNA (60), long non-coding RNA (46), and tRNA (1). Lee et al. obtained EVs from $\mathrm{M} \varphi$ treated with Shiga toxin 2a toxoids and found that they express higher levels of mRNAs encoding the pro-inflammatory cytokines IL-1 $\beta$ and IL-8, thereby exacerbating inflammation (9). Zhu et al. evaluated the features of $\mathrm{M} \varphi$-EVs and EVs derived from tumor-associated $\mathrm{M} \varphi$ (TAMEVs) (72) and found that different RNA processing proteins resulted in different RNA profiles. These results indicate that EVs that transport mRNA may be internalized and translated. MiRNA incorporated in EVs could circulate in the blood without degradation from blood RNAse activity (3). In addition, $\mathrm{M} \varphi-\mathrm{EV}$ miRNAs participate in the immune response (51), induce mesenchymal stem cell differentiation (57), regulate the tumor-associated microenvironment $(73,74)$, and mediate cell proliferation and migration (52). However, to date, few studies have investigated the presence of DNA in EVs (3).

In recent years, proteomic studies have provided new insights into the protein components of $\mathrm{M} \varphi$-EVs. Yao et al. reported a number of differentially expressed proteins in IFN- $\alpha$-treated $\mathrm{M} \varphi$-EVs (35), including 74 upregulated and 20 downregulated proteins involved in antiviral-related pathways. In another study, 22 upregulated proteins in LPS-induced M $\varphi$-EVs activated the NOD-like receptor signaling pathway and the NLRP3 inflammasome in patients with acute liver injury (25). Huang et al. screened proteins from silica-exposed $\mathrm{M} \varphi$-EVs and identified 291 differentially expressed proteins; the SPP1 protein was found to play a critical role in the response to silicosis (36). These findings emphasize that the biological functions of EV proteins vary under different conditions.

EVs can also deliver soluble mediators such as cytokines and enzymes. Haque et al. investigated the role of $\mathrm{M} \varphi$-EVs exposed to cigarette smoke condensate in HIV patients and found an association with catalase upregulation (29). In colitis patients, EVs transmitting CC chemokine 1 directly interact with CCR8 to alleviate colon damage and relieve inflammation (12).

Lipids also play an important role in the functions of $\mathrm{M} \varphi$-EVs. Kadiu et al. applied lipidomic analysis to explore how $\mathrm{M} \varphi$-EVs facilitate HIV-1 infection (75) and found that MVs and exosomes derived from $\mathrm{M} \varphi$ have unique lipid profiles. Specifically, viral membranes enriched with lipids, such as glycerophosphoserine, sphingomyelin, and dihydrosphingomyelin, were readily detected in the MV fraction; by contrast, phosphatidylethanolamine/ ceramide was identified only in the exosome population (75). However, the complete lipid profiles of $\mathrm{M} \varphi$-EVs are poorly understood and require further study.

\section{Biogenesis of $M \varphi-E V s$}

The mechanisms of microvesicle biogenesis are associated with outward budding and fission of the plasma membrane. Apoptotic bodies are released as blebs in cells undergoing apoptosis (3). The biogenesis of exosomes is a complex and dynamic process. Invagination of the plasma membrane initiates the first step of exosome biogenesis and produces endocytic 
TABLE 1 | The cargos transmitted by $M \varphi$-EVs to recipient cells.

\begin{tabular}{|c|c|c|c|c|c|}
\hline $\begin{array}{l}\text { EVs } \\
\text { Source }\end{array}$ & $\begin{array}{l}\text { Precondition of } \\
\text { Macrophages }\end{array}$ & Disease model & Cargos & Mechanism & Reference \\
\hline $\mathrm{M} 2-\mathrm{EV} s$ & - & $\begin{array}{l}\text { Hepatocellular } \\
\text { carcinoma }\end{array}$ & Integrin $\alpha_{M} \beta_{2}(C D 11 b / C D 18)$ & $\begin{array}{l}\text { Promote invasive and metastasis of hepatocellular } \\
\text { carcinoma cells via activating MMP-9 }\end{array}$ & (24) \\
\hline $\mathrm{M \phi}$-EVs & Induced by LPS & Acute liver injury & $\begin{array}{l}\text { Differentially expressed } \\
\text { proteins like IL1rn, Gbp2 }\end{array}$ & $\begin{array}{l}\text { Activate the NLRP3 and NOD-like receptor signaling } \\
\text { pathway }\end{array}$ & $(25)$ \\
\hline M2b-EVs & - & Colitis & CCL1 chemokine & $\begin{array}{l}\text { Interact with CCR8 to increase IL- } 4 \text { expression and Treg } \\
\text { percentages }\end{array}$ & $(12)$ \\
\hline $\mathrm{M} \phi-E V s$ & $\begin{array}{l}\text { Treated with endotoxin and } \\
\text { nigericin }\end{array}$ & $\begin{array}{l}\text { Autoimmune } \\
\text { diseases }\end{array}$ & $\begin{array}{l}\text { The immune response-related } \\
\text { proteins }\end{array}$ & Activate NF- $\kappa \mathrm{B}$ signaling pathway & (26) \\
\hline TAM-EVs & $\begin{array}{l}\text { Reprogramed glioblastoma- } \\
\text { derived EVs }\end{array}$ & Glioblastoma & Arginase-1 & Promote tumor growth & $(27)$ \\
\hline $\mathrm{M} \phi-E V s$ & Stimulated with angiotensin ॥ & $\begin{array}{l}\text { Bleomycin } \\
\text {-induced lung } \\
\text { fibrosis }\end{array}$ & Angiotensin II type 1 receptor & Activate TGF- $\beta /$ smad $2 / 3$ pathway & $(28)$ \\
\hline $\mathrm{M} \phi$-EVs & $\begin{array}{l}\text { Exposed to cigarette smoke } \\
\text { condensate }\end{array}$ & HIV-1 & Catalase & $\begin{array}{l}\text { Protect U937 cells from oxidative stress and HIV-1 } \\
\text { replication }\end{array}$ & $(29)$ \\
\hline $\mathrm{M} \phi$-EVs & Exposed to silica & Silicosis & BIP, XBP1s and $P$-elF2 $\alpha$ & Induce endoplasmic reticulum stress & $(30)$ \\
\hline $\mathrm{M} \phi$-EVs & High glucose-treated & $\begin{array}{l}\text { Diabetic } \\
\text { nephropathy }\end{array}$ & TGF- $\beta 1$ mRNA & Activate TGF- $\beta 1 /$ Smad3 signaling pathways & (31) \\
\hline Mф-EVs & Oxidized LDL-stimulated & AS & EVs transfer & $\begin{array}{l}\text { Attenuate the growth and tube formation of endothelial } \\
\text { cells }\end{array}$ & $(32)$ \\
\hline $\mathrm{M} \phi$-EVs & $\begin{array}{l}\text { Treated with Shiga toxin } 2 a \\
\text { toxoids }\end{array}$ & Cells death & $\begin{array}{l}\text { Globotriaosylceramide }\left(\mathrm{Gb}_{3}\right) \text {, } \\
\text { IL-1 } \beta \text { and IL-8 mRNAs }\end{array}$ & $\begin{array}{l}\text { Activate stress-associated MAPKs and induce ER stress in } \\
\text { Gb3-expressing cells }\end{array}$ & (9) \\
\hline$M \phi-E V s$ & - & - & Integrin $\beta 1$ & $\begin{array}{l}\text { Promote internalization of integrin } \beta 1 \text { in primary HUVECs, } \\
\text { make the internalized integrin } \beta 1 \text { accumulate in the } \\
\text { perinuclear region and not recycled back to the plasma } \\
\text { membrane. }\end{array}$ & (33) \\
\hline Mф-EVs & - & $\begin{array}{l}\text { Breast } \\
\text { adenocarcinoma }\end{array}$ & $\begin{array}{l}\text { Human a disintegrin and } \\
\text { metalloproteinase } 15\end{array}$ & $\begin{array}{l}\text { Enhance binding affinity for integrin } \alpha v \beta 3 \text { in an RGD- } \\
\text { dependent manner and suppress vitronectin- and } \\
\text { fibronectin-induced cell adhesion, growth, and migration }\end{array}$ & (34) \\
\hline$M \phi-E V s$ & $\begin{array}{l}\text { Treated with interferon- } \alpha \text { or } \\
\text { not }\end{array}$ & Viral infection & $\begin{array}{l}\text { Differentially expressed } \\
\text { proteins }\end{array}$ & $\begin{array}{l}\text { Be involved in two of the top biological process categories: } \\
\text { "Defense response to virus" and "Type I interferon signaling } \\
\text { pathway" }\end{array}$ & (35) \\
\hline$M \phi-E V s$ & Exposed to silica & Silicosis & SPP1 protein & $\begin{array}{l}\text { Phagocytosed by fibroblasts and generate corresponding } \\
\text { myofibroblasts }\end{array}$ & $(36)$ \\
\hline Mф-EVs & - & - & Leukotriene B(4) & $\begin{array}{l}\text { Produce chemotactic eicosanoids and induced granulocyte } \\
\text { migration in the present of } \mathrm{Ca}\left(2^{+}\right) \text {-ionophore and } \\
\text { arachidonic acid }\end{array}$ & $(37)$ \\
\hline $\mathrm{M} \phi$-EVs & $\begin{array}{l}\text { Exposed or not to either LPS } \\
\text { or to stationary phase } \\
\text { Leishmania mexicana } \\
\text { promastigotes }\end{array}$ & $\begin{array}{l}\text { Parasite } \\
\text { infection } \\
\text { (Leishmania) }\end{array}$ & $\begin{array}{l}\text { Mexicana surface protease } \\
\text { GP63 }\end{array}$ & $\begin{array}{l}\text { Induce signaling molecules and transcription factors in } \\
\text { naive macrophages }\end{array}$ & (38) \\
\hline $\mathrm{M} \phi$-EVs & $\begin{array}{l}\text { Exposed to calcium oxalate } \\
\text { monohydrate crystals }\end{array}$ & $\begin{array}{l}\text { Kidney stone } \\
\text { disease }\end{array}$ & $\begin{array}{l}\text { L-plastin, coronin-like protein, } \\
\text { pyruvate kinase, actin-related } \\
\text { protein } 3, \mathrm{HSP} 90 \beta \text {, and } \\
\text { vimentin }\end{array}$ & $\begin{array}{l}\text { Activate inflammasome, promote monocyte and T-cell } \\
\text { migration, monocyte activation and macrophage } \\
\text { phagocytic activity }\end{array}$ & (39) \\
\hline $\mathrm{M} \phi$-EVs & - & $\begin{array}{l}\text { Inflammation } \\
\text { brain }\end{array}$ & $\begin{array}{l}\text { Brain derived neurotrophic } \\
\text { factor }\end{array}$ & $\begin{array}{l}\text { Interact with brain microvessel endothelial cells via the } \\
\text { integrin LFA-1 and ICAM-1, the carbohydrate-binding C- } \\
\text { type lectin receptors }\end{array}$ & $(40)$ \\
\hline $\mathrm{M \phi}$-EVs & Stimulated with angiotensin ॥ & Hypertension & ICAM-1 and PAl-1, miR-17 & $\begin{array}{l}\text { Increase the expression of ICAM1 and PAI-1 in human } \\
\text { coronary artery endothelial cells }\end{array}$ & $(41)$ \\
\hline Mф-EVs & $\begin{array}{l}\text { Mock-infected or infected } \\
\text { with the macrophage-tropic } \\
\text { HIV-1 BaL strain }\end{array}$ & HIV & $\begin{array}{l}48 \text { miRNAs (e.g., miR-29a, } \\
\text { miR-150) }\end{array}$ & Unclear & $(42)$ \\
\hline $\begin{array}{l}\text { M2a-EVs, } \\
\text { M2b-EVs, } \\
\text { M2c-EVs }\end{array}$ & - & - & $\begin{array}{l}\text { MRNA of } \| 1 \mathrm{~b}, \mathrm{CCL} 2 \text {, } \\
\mathrm{CCL} 7, \mathrm{CCL} 3, \mathrm{Pf} 4\end{array}$ & $\begin{array}{l}\text { Affect the TLR, TNF, NLR, and NF- } \kappa B \text { signaling pathways } \\
\text { in recipient cells }\end{array}$ & $(43)$ \\
\hline M2-EVs & - & Lung cancer & AGAP2-AS1 & $\begin{array}{l}\text { Strengthen the radioresistance of radioresistant lung } \\
\text { cancer cells via upregulating NOTCH2 and downregulating } \\
\text { miR-296 }\end{array}$ & $(44)$ \\
\hline M2-EVs & - & $\begin{array}{l}\text { Pancreatic } \\
\text { cancer }\end{array}$ & LncRNA SBF2-AS1 & $\begin{array}{l}\text { Suppress tumorigenic ability of pancreatic cancer via } \\
\text { repressing miR-122-5p and upregulating XIAP }\end{array}$ & $(45)$ \\
\hline
\end{tabular}


TABLE 1 | Continued

\begin{tabular}{|c|c|c|c|c|c|}
\hline $\begin{array}{l}\text { EVs } \\
\text { Source }\end{array}$ & $\begin{array}{l}\text { Precondition of } \\
\text { Macrophages }\end{array}$ & Disease model & Cargos & Mechanism & Reference \\
\hline M2-EVs & - & $\begin{array}{l}\text { Hypertrophic } \\
\text { scar }\end{array}$ & LncRNA-ASLNCS5088 & $\begin{array}{l}\text { Modulate glutaminases expression in fibroblasts via } \\
\text { targeting miR-200c-3p }\end{array}$ & $(46)$ \\
\hline M1-EVs & - & $\begin{array}{l}\text { Inflammatory } \\
\text { bowel disease }\end{array}$ & MiR-21a-5p & $\begin{array}{l}\text { Decrease E-cadherin expression and excessively activate } \\
\text { ILC2 via promoting GATA-3 }\end{array}$ & $(47)$ \\
\hline M1-EVs & - & $\begin{array}{l}\text { Myocardial } \\
\text { infarction }\end{array}$ & MiR-155 & $\begin{array}{l}\text { Suppress Sirt1/AMPK } \alpha 2 \text {-endothelial nitric oxide synthase } \\
\text { and RAC1-PAK2 signaling pathways through targeting } \\
\text { RAC1, PAK2, Sirt1, and AMPK } \alpha 2\end{array}$ & $(48)$ \\
\hline M2-EVs & Treated with IL-4- & AS & MiR-99a/146b/378a & $\begin{array}{l}\text { Target NF- } \kappa \mathrm{B} \text { and } \mathrm{TNF}-\alpha \text { signaling pathways to suppress } \\
\text { inflammation }\end{array}$ & $(49)$ \\
\hline$M \phi-E V s$ & - & $\begin{array}{l}\text { Idiopathic } \\
\text { pulmonary } \\
\text { fibrosis }\end{array}$ & MiR-142-3p & $\begin{array}{l}\text { Decrease the expression of TGF } \beta-R 1 \text { and profibrotic genes } \\
\text { in alveolar epithelial cells and lung fibroblasts }\end{array}$ & $(50)$ \\
\hline $\mathrm{M} \phi-E V s$ & Induced by LPS & Inflammation & $\begin{array}{l}\text { MiR-146a、miR-146b, miR } \\
-21-3 p\end{array}$ & $\begin{array}{l}\text { Secrete various chemokines and cytokines, activate } \\
\text { Immune signaling pathways }\end{array}$ & $(51)$ \\
\hline $\mathrm{M} \phi-\mathrm{EV} s$ & Induced by nicotine & AS & MiR-21-3p & $\begin{array}{l}\text { Promote vascular smooth muscle cells proliferation and } \\
\text { migration through targeting PTEN }\end{array}$ & $(52)$ \\
\hline$M \phi-E V s$ & $\begin{array}{l}\text { Stimulated by oxidized low- } \\
\text { density lipoprotein }\end{array}$ & AS & MiR-146a & $\begin{array}{l}\text { Increase the release of reactive oxygen species ROS and } \\
\text { neutrophil extracellular traps NETs via targeting SOD2 }\end{array}$ & (53) \\
\hline M $\phi-E V s$ & Induced by deoxycholic acid & $\begin{array}{l}\text { Intestinal } \\
\text { metaplasia }\end{array}$ & MiR-30a-5p & $\begin{array}{l}\text { Promote the CDX2 expression and suppressed the } \\
\text { proliferation of human gastric epithelial cells by targeting } \\
\text { FOXD1 }\end{array}$ & (54) \\
\hline Mф-EVs & Induced by LPS & Hepatic fibrosis & MiR-103-3p & $\begin{array}{l}\text { Target KLF4 to promote the proliferation and activation of } \\
\text { hepatic stellate cells }\end{array}$ & $(55)$ \\
\hline M $\phi-E V s$ & $\begin{array}{l}\text { Stimulated by Treponema } \\
\text { pallidum }\end{array}$ & Syphilis & MiR-146a-5p & $\begin{array}{l}\text { Suppress monocyte transendothelial migration and } \\
\text { endothelial permeability via targeting JAM-C }\end{array}$ & $(56)$ \\
\hline M2-EVs & - & Fracture & MiR-5106 & $\begin{array}{l}\text { Induce bone mesenchymal stem cells towards osteoblastic } \\
\text { fate by targeting salt-inducible kinase } 2 \text { and } 3\end{array}$ & $(57)$ \\
\hline $\begin{array}{l}\text { Diabetic- } \\
\text { Mф-EVs }\end{array}$ & - & Diabetic fracture & MiR-144-5p & $\begin{array}{l}\text { Inhibit bone mesenchymal stem cells osteogenesis } \\
\text { differentiation by targeting Smad1 }\end{array}$ & (58) \\
\hline Mф-EVs & High glucose-treated & Type 2 diabetes & MiR-210 & $\begin{array}{l}\text { Bind with mRNA sequences of NDUFA4 gene to impair } \\
\text { glucose uptake and mitochondrial complex IV activity }\end{array}$ & (59) \\
\hline M $\phi-E V s$ & - & $\begin{array}{l}\text { Spontaneous } \\
\text { abortion }\end{array}$ & MiR-153-3p & $\begin{array}{l}\text { Suppress the proliferation and migration of trophoblast } \\
\text { cells through the IDO/STAT3 pathway. }\end{array}$ & (60) \\
\hline M2-EVs & - & $\begin{array}{l}\text { Pulmonary } \\
\text { fibrosis }\end{array}$ & MiR-328 & $\begin{array}{l}\text { Enhance pulmonary interstitial fibroblast proliferation by } \\
\text { targeting FAM13A }\end{array}$ & $(61)$ \\
\hline M1-EVs & $\begin{array}{l}\text { Hypoxia/serum deprivation- } \\
\text { induced }\end{array}$ & $\begin{array}{l}\text { Myocardial } \\
\text { infarction }\end{array}$ & MiR-222 & Promote BMSCs apoptosis by targeting Bcl-2 & $(62)$ \\
\hline $\mathrm{M} \phi-\mathrm{EV} s$ & - & $\begin{array}{l}\text { Ischemia- } \\
\text { reperfusion } \\
\text { injury }\end{array}$ & MiR-148a & $\begin{array}{l}\text { Suppress the expression of thioredoxin-interacting protein } \\
\text { and inactivate the TLR4/NF- } \mathrm{B} \text { /NLRP3 signaling pathway }\end{array}$ & (63) \\
\hline $\mathrm{M} \phi-\mathrm{EV} s$ & $\begin{array}{l}\text { Stimulated by hypoxia- } \\
\text { reoxygenation }\end{array}$ & $\begin{array}{l}\text { Ischemia- } \\
\text { reperfusion } \\
\text { injury }\end{array}$ & MiR-29a & $\begin{array}{l}\text { Promote inflammatory cytokines secretion and } \\
\text { cardiomyocyte pyroptosis by targeting MCL-1 }\end{array}$ & (64) \\
\hline$M \phi-E V s$ & - & Type 2 diabetes & MiR-29a & Induce insulin resistance through targeting PPAR $\gamma$ signaling & $(65)$ \\
\hline M1-EVs & - & $\begin{array}{l}\text { Carotid artery } \\
\text { injuries }\end{array}$ & MiR-222 & $\begin{array}{l}\text { Target CDKN1B and CDKN1C to promote vascular } \\
\text { smooth muscle cell proliferation and migration }\end{array}$ & (66) \\
\hline M2-EVs & - & $\begin{array}{l}\text { Acute } \\
\text { myocardial } \\
\text { infarction }\end{array}$ & MiR-1271-5p & $\begin{array}{l}\text { Decrease cardiomyocyte apoptosis via decreasing SOX6 } \\
\text { expression }\end{array}$ & $(67)$ \\
\hline $\mathrm{M} \phi-E V s$ & $\begin{array}{l}\text { Activated by Toll-like receptor } \\
3\end{array}$ & $\begin{array}{l}\text { Hepatitis C virus } \\
\text { infection }\end{array}$ & MiR-29 & $\begin{array}{l}\text { Induce the expression of IFN- } \alpha \text { - and IFN-stimulated genes } \\
\text { (ISGs, MxA, OAS-1, and OAS-2) in human hepatic cells }\end{array}$ & (68) \\
\hline M1-EVs & - & Breast cancer & MiR-130, MiR-33 & $\begin{array}{l}\text { Perform anti-tumor effect by polarizing M } \phi \text { from M2 to M1 } \\
\text { phenotype }\end{array}$ & (69) \\
\hline M2-EVs & - & Asthma & MiR-370 & $\begin{array}{l}\text { Reduce cell apoptosis, relive inflammation in vitro and in } \\
\text { vivo through suppressing the FGF1/MAPK/STAT1 axis }\end{array}$ & (70) \\
\hline
\end{tabular}

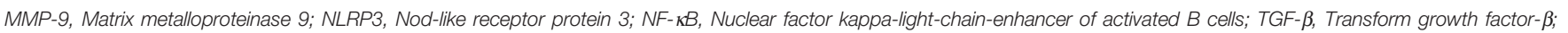
Smad2/3, Small mothers against decapentaplegic 2/3; MAPK, Mitogen-activated protein kinases; ER, Endoplasmic reticulum; HUVECs, Human umbilical vein endothelial cells; LFA-1, Lymphocyte function-associated antigen 1; ICAM-1, Intercellular adhesion molecule 1; PAI-1, Plasminogen activator inhibitor-1; TLR, Toll-like receptors; TNF, Tumor necrosis factor; NLR, NOD-like receptor; RAC1, RAS-related C3 botulinus toxin substrate 1; PAK2, p21-activated kinase 2; Sirt1, Sirtuin 1; AMPKo2, Adenosine monophosphate-activated protein kinas alpha 2; AS, Atherosclerosis; PTEN, Phosphatase and tensin homolog; ROS, Reactive oxygen species; NETs, Neutrophil extracellular traps; SOD2, Superoxide dismutase 2; CDX2, Caudalrelated homeobox transcription factor 2; FOXD1, Forkhead Box D1; KLF4, Krüppel-like factor 4; JAM-C, Junctional adhesion molecule C; NDUFA4, NADH dehydrogenase ubiquinone 1 alpha subcomplex 4; IDO, Indoleamine 2,3-dioxygenase; STAT3, Signal Transducers and Activators of Transcription 3; FAM13A, Family with sequence similarity 13, member A; Bcl-2, Bcell lymphoma -2; MCL-1, Myeloid cell leukemia-1; PPARy, Peroxisome proliferator-activated receptor gamma; CDKN1B, Cyclin Dependent Kinase Inhibitor 1B; CDKN1C, Cyclin Dependent Kinase Inhibitor 1C; SOX6, Sox family transcription factors 6; FGF1, Fibroblast growth factor 1. 


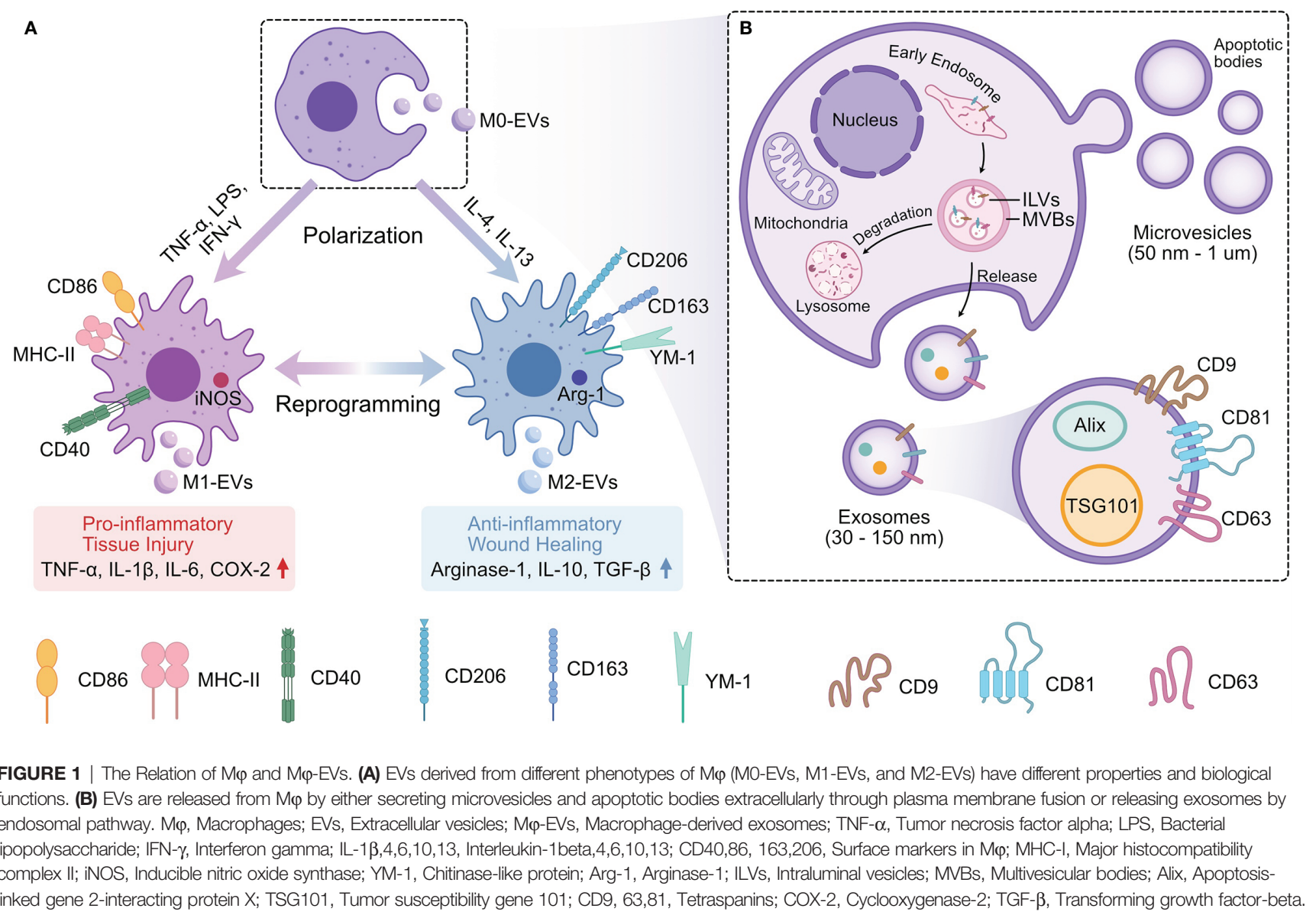

vesicles. The fusion of multiple endocytic vesicles leads to the formation of early endosomes (EEs). Many intercellular cargoes are encapsulated in such EEs in a clathrin- or caveolindependent or independent manner $(76,77)$. With the assistance of the Golgi complex, EEs invaginate and mature into late endosomes known as multivesicular bodies (MVBs) (2). Inward membrane budding results in the formation of intraluminal vesicles (ILVs), which are housed in MVBs (78). MVBs show two types of reversion: they may fuse with the plasma membrane and release ILVs into the extracellular space as exosomes, or they may fuse with lysosomes or autophagosomes and ultimately lead to degradation (4). Endosomal sorting complex required for transport (ESCRT) is the best-described mechanism underlying MVB formation and protein sorting in MVBs (79). ESCRT includes four different protein complexes, ESCRT-0, -I, -II, -III (80). The ESCRT-0, -I and ESCRT-II complexes form a recognition domain in the endosomal membrane that recognizes and ubiquitinates membrane proteins. The ESCRT-III complex is responsible for membrane budding and the release of ILVs (81). Other critical players include Sytenin-1, TSG101, ALIX, Rab GTPases, Pmel17, and tetraspanins (4). In addition to proteins and ceramides, lipids such as sphingomyelinases are also involved in the biogenesis of exosomes (82).
Furthermore, stimulation could influence $\mathrm{M} \varphi-\mathrm{EV}$ cargo sorting or ultimate release in the biogenesis of $\mathrm{M} \varphi$-EVs. $\mathrm{M} \varphi$ exposed to irradiated apoptotic cancer cells activate peroxisome proliferator-activated receptor gamma (PPAR $\gamma)$ and increase the expression of phosphatase and tensin homolog (PTEN) in $\mathrm{M \varphi -}$ EVs (83). Similarly, $\mathrm{M} \varphi$ exposed to extracellular adenosine triphosphate (ATP) activate the P2X7 signaling pathway and increase calpain activity, ultimately leading to IL-1 $\beta$ expression and loading of unconventional proteins into $\mathrm{M} \varphi$-EVs $(84,85)$. Interestingly, the more released of $\mathrm{M} \varphi$-EVs would result from lipopolysaccharide (LPS) stimulation, and the mechanism is related to upregulation of $\operatorname{Rab} 27 \mathrm{a}$ and $\mathrm{Rab} 27 \mathrm{~b}$, while it is inhibited by IL-25 (86).

\section{Relationship Between $\mathbf{M} \varphi$ and $\mathbf{M} \varphi-E V s$}

The description of the $\mathrm{M} \varphi$ phenotype is widely accepted: classically activated or inflammatory $\mathrm{M} 1 \mathrm{M} \varphi$ are induced by IFN- $\gamma$, TNF- $\alpha$ or bacterial LPS, whereas alternatively activated or anti-inflammatory $\mathrm{M} 2 \mathrm{M} \varphi$ are polarized by IL-4 and IL-13 (87, 88). Plasticity is an important property of $\mathrm{M} \varphi$ (89). Cytokines in the microenvironment can alter the phenotype of $\mathrm{M \varphi}$ (90). Different phenotypes have different functions; for example, $\operatorname{M1M} \varphi$ secrete higher levels of pro-inflammatory cytokines, exerting potent antimicrobial and antitumor activities that 
impair tissue regeneration and wound healing (91-93). By contrast, $\mathrm{M} 2 \mathrm{M} \varphi$ have anti-inflammatory effects that remove debris and apoptotic cells, promote angiogenesis, and facilitate fibrosis, tissue repair, and wound healing (94-96).

There are three major phenotypes of $\mathrm{M} \varphi$-EVs: unpolarized M0M $\varphi$-derived EVs (M0-EVs), M1M $\varphi$-derived EVs (M1-EVs), and $\mathrm{M} 2 \mathrm{M} \varphi$-derived EVs (M2-EVs) (97). Their biological functions vary depending on the parental cell properties. For instance, in the pathogenesis of atherosclerosis (AS), M1-EVs containing a high level of miR-155 suppress the proliferation of fibroblasts and promote the development of AS (98), while M2EVs deliver miR-1271-5p to suppress cardiomyocyte apoptosis and perform cardiac repair (67). Moradi-Chaleshtori et al. reported that $\mathrm{M} 1-\mathrm{EV}$ s polarize $\mathrm{M} \varphi$ from the $\mathrm{M} 2$ to $\mathrm{M} 1$ phenotype and have antitumor effects by carrying miR-130 and miR-33 (69). M2-EVs promote cell invasion in breast cancer by transporting miR-223 to target the Mef2c/ $\beta$-catenin pathway (99). Furthermore, each EV phenotype has polarization-specific control in the bone repair process. M0EVs and M2-EVs enhance bone regeneration, while M1-EVs inhibit bone repair (100).

\section{IMMUNOMODULATORY EFFECTS OF M $\varphi$-EVs in Chronic Inflammatory Disease}

Inflammation is the body's defense response to stimuli such as infection or injury, and it can be divided into acute and chronic phases. Acute inflammation is rapid in onset and short in duration, mainly characterized by exudative lesions. Chronic inflammation can lead to pathological changes in tissues and organs, which in turn cause diverse chronic diseases, including diabetes, cancer, cardiovascular disease, respiratory disease, and gastrointestinal disease $(101,102)$.

Chronic diseases are driven by pathological inflammation, eventually leading to tissue damage (103). In short, disorders resulting from inflammation-related pathways are the primary mechanism leading to chronic disease.

EVs play a vital role in maintaining tissue homeostasis and regulating disease progression as another mode of cellular interaction $(104,105)$. Numerous studies have elucidated the impact of $\mathrm{M} \varphi$-EVs on chronic inflammation and disease. EVs derived from different $M \varphi$ have unique effects under various pathological conditions (106, 107) (Figure 2).

\section{Cardiovascular Disease}

AS plays a prominent role in coronary heart disease, cerebral infarction, and peripheral vascular disease (108). It is a multifactorial disease, and its exact pathogenesis has not been elucidated. Hypertension, hyperlipidemia, obesity, smoking, and diabetes are all risk factors for its development (109). AS is characterized by lesions in affected arteries starting from the intima, with lesions involving mainly large and medium arteries. It can lead to deposits of lipids and complex sugars, hemorrhage, thrombus formation, and many other conditions that eventually thicken and stiffen the arterial wall and narrow the vessel lumen. AS plaques are composed primarily of immune, foam, and inflamed smooth muscle cells (110).

AS is an inflammatory response caused by the retention of cholesterol-rich, B-type lipoproteins in susceptible areas of medium and large arteries (111). Dysregulation of the balance between cellular and systemic cholesterol promotes the deposition of such lipoproteins in the arterial wall (109).

The development of AS is closely associated with endothelial cell damage, vascular inflammation, and massive accumulation of $M \varphi$. The imbalance between $M \varphi$ recruited to plaques and $M \varphi$ migration from plaques to regional lymph nodes causes deposition of lipid-laden $\mathrm{M} \varphi$ in the arterial wall, further promoting the inflammatory progression of AS. Thus, $\mathrm{M} \varphi$ migration regulates the development of AS $(108,112)$. EVs mediate intercellular communication in atherosclerotic plaques (113). Furthermore, activated monocytes or $\mathrm{M} \varphi$-EVs can propagate inflammatory signals and modulate AS development via various pathways (114-116). Nguyen et al. reported that EVs secreted from $M \varphi$ loaded with oxidized low density lipoprotein are taken up by naive $\mathrm{M} \varphi$ and inhibit $\mathrm{M} \varphi$ migration in vitro and in vivo (116). In addition, $\mathrm{M} \varphi$-EVs can block the migration of $\mathrm{M} \varphi$ to the chemokine stimulator CCL2, and EVs transport miR$146 \mathrm{a}$, which suppresses the expression of genes in $\mathrm{M} \varphi$ related to cell migration, such as HuR and IGF2BP1 (116). M $\varphi$ may also promote the progression of AS via activation of the NF- $\kappa B$ pathway. The modulatory effect of $\mathrm{M} \varphi-\mathrm{EV} s$ on $\mathrm{AS}$ is further evidenced by their ability to regulate hematopoietic stem cells differentiation and necrosis by suppressing the TNF- $\alpha / N F-\kappa B$ signaling pathway (49). Furthermore, Zhu et al. isolated EVs from nicotine-treated $M \varphi$ and illustrated that they aggravate the development of AS by transporting the exosomal miR-21-3p target PTEN, which enhances vascular smooth muscle cell migration and proliferation (52).

Oxidative stress and inflammation are closely related, and they form a feed-forward loop that promotes the development of AS. During AS, M $\varphi$ produce significant levels of reactive oxygen species (ROS) via mitochondrial metabolism (109). M1M $\varphi$ enhance aerobic glycolysis and reduce mitochondrial activity. In contrast, $\mathrm{M} 2 \mathrm{M} \varphi$ mediate mitochondrial oxidative phosphorylation (117). Bouchareychas et al. isolated EVs from mouse bone marrow-derived M $\varphi$ treated with IL-4 and applied these EVs to naive BMDMs, which resulted in enhanced ATP production and cellular respiration. These results indicate that EVs can effectively regulate cellular reprogramming by improving energy metabolism (49). M $\varphi$-derived EVs treated with superoxide dismutase 2, a target of oxidized low density lipoprotein, showed increased ROS production and the release of neutrophil extracellular traps via miR-146a (53).

$\mathrm{M} \varphi$ modulation plays an essential role in immunomodulatory processes during cardiac repair and in remodeling postmyocardial infarction (118). Hypoxia/serum deprivationinduced M1-EVs transport miR-222, which promotes apoptosis and inhibits viability in bone marrow mesenchymal stem cells by targeting B-cell lymphoma-2 (62). miR-155 is predominantly expressed in $\mathrm{M} \varphi$ and cardiac fibroblasts and is 


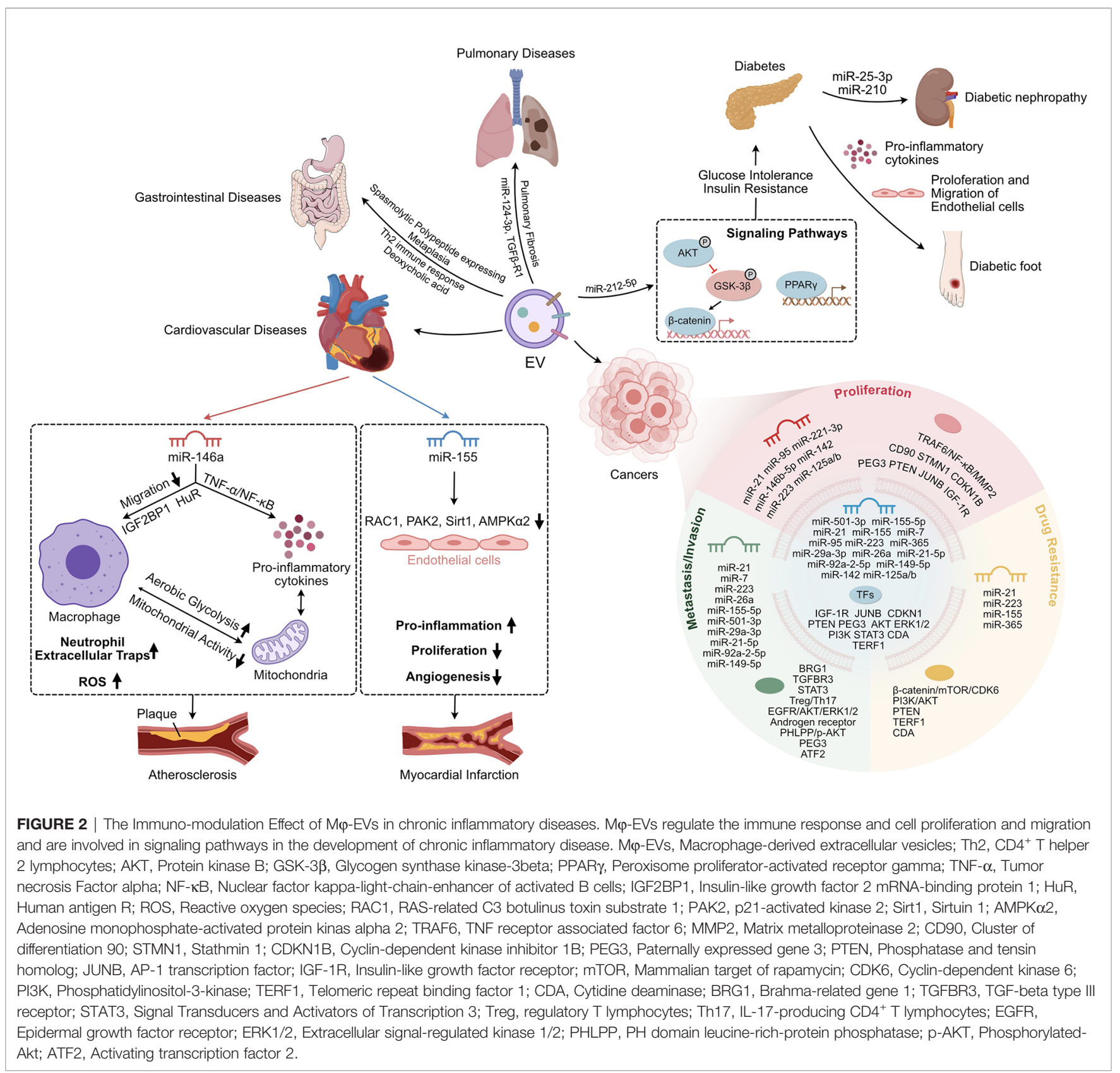

one of the most abundant miRNAs in M1-EVs (119). The expression of miR-155 is upregulated in $\mathrm{M} \varphi$-EVs from the hearts of mice after acute myocardial infarction (AMI). EVs enriched with miR-155 inhibit the proliferation of fibroblasts and promote the inflammatory response; a deficiency of miR-155 decreases the incidence of cardiac rupture after AMI and improves cardiac function (98). Previous studies have observed angiogenesis-inhibiting effects of M1M $\varphi$, but the mechanism of action is not entirely understood (120). M1-EVs transfer miR155 to endothelial cells, reducing their angiogenic ability by downregulating miR-155 target genes including RAC1, PAK2, Sirt1, and AMPK $\alpha 2$ (48). Thus, inhibition of miR-155 expression may be a novel method for the clinical treatment of
MI. By contrast, M2-EVs transport miR-1271-5p, which suppresses apoptosis in cardiomyocytes and performs a cardiac repair function in AMI by targeting SOX6 (67).

Generally, ischemia-reperfusion is applied to restore coronary artery blood flow and relieve disease progression. However, numerous studies have demonstrated that ischemiareperfusion injury (IRI) can lead to cardiac dysfunction due to calcium overload and overproduction of free radicals such as ROS (121). Induction of hypoxia-reoxygenation is the main method for establishing IRI in animal models (64). Wang et al. demonstrated that $M \varphi$ subjected to hypoxia-reoxygenation are polarized toward $\mathrm{M} 1 \mathrm{M} \varphi$ and derived $\mathrm{EV}$ miR-29a to promote cardiomyocyte pyroptosis by targeting myeloid cell leukemia-1 
(64). M2-EVs alleviate cardiac dysregulation and $\mathrm{Ca}^{2+}$ overload, which relieves IRI. miR-148a within M2-EVs suppresses the expression of thioredoxin-interacting protein and inactivates the TLR4/NF- $\mathrm{KB} / \mathrm{NLRP} 3$ signaling pathway (63).

\section{Diabetes Mellitus}

The incidence of type 2 diabetes has risen sharply over the past few decades, with a global prevalence of over 300 million people (122). Type 2 diabetes accounts for approximately 95\% of diabetes cases and is characterized by hyperglycemia due to insulin resistance (IR) and relative insulin deficiency $(123,124)$. Obesity is a risk factor for type 2 diabetes. Moreover, chronic low-grade inflammation is a leading cause of obesity-induced IR (125).

The massive accumulation of pro-inflammatory $\mathrm{M} \varphi$ in adipose tissue and the liver is a distinguishing feature of obesity-induced chronic inflammation in tissues (126). M $\varphi$ could be the ultimate effector cells that secrete the major cytokines responsible for IR. M $\varphi$ in normal adipose tissue express CD206 receptors and release Arg-1, but those in inflamed tissues are polarized toward the M1 phenotype (127). In a previous study, administering EVs derived from adipose tissue $\mathrm{M} \varphi$ (ATM-EVs) from obese mice to lean mice caused glucose intolerance and IR, while administering lean mice ATMEVs to obese mice improved glucose tolerance and insulin sensitivity (128).

Chronic low-grade tissue inflammation is the main cause of IR, leading to islet $\beta$ cell failure. Qian et al. analyzed the effects on $\beta$ cells of M1-EVs and EVs isolated from islet-resident $\mathrm{M} \varphi$ from mice fed a high-fat diet (129) and found that miR-212-5p restricted insulin secretion by targeting the SIRT2 gene and regulating the Akt/GSK-3 $\beta / \beta$-catenin pathway (129). Moreover, miR-155, which is overexpressed in obese ATMEVs, suppresses the expression of PPAR $\gamma$ and impairs the inhibitory effects of insulin on glucose production (128). Similarly, miR-29a within ATM-EVs promotes obesity-induced IR by directly targeting PPAR $\gamma$ (65).

Many complications can occur during the late stages of diabetes. The persistence of diabetic inflammation activates inflammatory cells, which secrete inflammation-associated cytokines (130). A common complication of diabetes is difficulty healing. $\mathrm{M} \varphi$-EVs show a remarkable decrease in the release of pro-inflammatory cytokines, enhancing the proliferation and migration of endothelial cells and accelerating wound healing via their anti-inflammatory effects (131). Similar research has shown that M1-EVs can regulate $\mathrm{M} \varphi$ phenotypic reprogramming, repolarizing $\mathrm{M} 1 \mathrm{M} \varphi$ to $\mathrm{M} 2 \mathrm{M} \varphi$, which in turn promotes wound healing (132). Bone homeostasis is also disturbed by diabetes mellitus. Zhang et al. isolated EVs from diabetic bone marrow-derived $\mathrm{M} \varphi$ and found that they transport miR-144-5p, which inhibits osteogenesis differentiation by targeting Smad1 and suppressing facture repair in vivo (58). Diabetic nephropathy is a peripheral small artery occlusive disease caused by diabetic neuropathy and lower extremity vasculopathy. M2-EVs that transport miR-25-3p may alleviate podocyte injury induced by high glucose levels by activating autophagy of the cells through suppression of
DUSP1 expression (133). Zhu et al. found that M $\varphi$-derived EVs treated with high levels of glucose might activate glomerular mesangial cells through the TGF- $\beta 1 / \mathrm{Smad} 3$ pathway, promote proliferation, and induce the production of fibrotic and inflammatory factors (31). Similarly, high-glucosetreated $\mathrm{M} \varphi$-derived EVs induce overexpression of inflammatory cytokines and activate NF- $\kappa \mathrm{B}$ p65 signaling pathways (134). ATM-EVs contain high levels of miR-210, and miR-210 in ATM-EVs has been shown to regulate glucose uptake and mitochondrial chain complex IV activity by targeting NDUFA4 gene expression, which promotes the pathogenesis of diabetes (59).

These findings highlight the importance of $\mathrm{M} \varphi-\mathrm{EV}$ s in adipose tissue and suggest that the contents and functions of ATM-EVs vary with the ATM phenotype.

\section{Cancer}

Cancer is the leading cause of death worldwide (135). In 2012, approximately 14.1 million new cancer cases and 8.2 million cancer deaths were recorded worldwide (135). Furthermore, with the aging population, the incidence and mortality rate of cancer have rapidly been increasing, imposing a significant burden on society. Inflammation plays a crucial role in the development of cancer (136). The "seed and soil" theory proposed in 1889 (137) compares cancer cells to seeds and the human microenvironment to soil and postulates that whether a tumor metastasizes depends on whether the soil meets the growth conditions of the seed (137). In recent years, more studies have focused on the regulatory roles of active immune cells such as $\mathrm{M} \varphi$, neutrophils, and mast cells in the tumor microenvironment (TME) $(138,139)$. Among such cells, TAMs play the most critical role in the TME $(140,141)$.

$\mathrm{M} \varphi$-EVs have diverse effects on the TME under various pathological conditions $(4,142,143)$. For example, EVs transport apolipoproteins from TAMs to gastric cancer cells to promote cell migration (144), the expression of matrix metalloproteinase- 2 , and the pathogenesis of abdominal aortic aneurysms by activating the JNK and p38 signaling pathways (145).

EVs mediate intercellular communication in the TME via miRNA-induced epigenetic modifications in recipient cells. EVs miRNAs can regulate tumor cell migration, invasion, and drug resistance via various mechanisms, which in turn affect tumorigenesis (Table 2).

In recent years, proteomics has dramatically facilitated the study of proteomic profiles of EVs, and research on $\mathrm{M} \varphi$-EVs has provided new insights into how the TME is regulated $(161,162)$. A thorough comparative proteomic analysis of EVs revealed that TAM-derived exosomal proteins are responsible mainly for RNA processing and proteolytic functions and determined that recipient cells have an improved capacity to degrade denatured or misfolded proteins after uptake of TAM-EVs, which enhances their survival in the TME (72). Furthermore, TAM-EVs have molecular profiles associated with Th1/M1 polarization profiles; they enhance inflammation and immune responses and promote the proliferation and activation of T cells ex vivo. Thus, TAMEVs are potent stimulators of antitumor immunity (163). They also activate the matrix metalloproteinase- 9 signaling pathway to 
TABLE 2 | The biological functions of M $\varphi$-EV miRNAs in TME.

\begin{tabular}{|c|c|c|c|c|}
\hline EVs sources & $\begin{array}{l}\text { Disease } \\
\text { model }\end{array}$ & MiRNAs & Mechanism & Reference \\
\hline M1-EVs & $\begin{array}{l}\text { Breast cancer } \\
\text { cells }\end{array}$ & $\begin{array}{l}\text { MiR-130, } \\
\text { MiR-33 }\end{array}$ & Perform anti-tumor effect by polarizing macrophage from M2 to M1 phenotype & (69) \\
\hline M2-EVs & $\begin{array}{l}\text { Colorectal } \\
\text { cancer }\end{array}$ & $\begin{array}{l}\text { MiR-21-5p, } \\
\text { MiR-155-5p }\end{array}$ & Downregulate BRG1 expression, enhance colorectal cancer cells migration and invasion & $(107)$ \\
\hline M2-EVs & GC & MiR-21 & $\begin{array}{l}\text { Suppress cell apoptosis and strengthen activation of PI3K/AKT signaling pathway via down- } \\
\text { regulation of PTEN }\end{array}$ & $(146)$ \\
\hline TAMs-EVs & PDAC & MiR-501-3p & $\begin{array}{l}\text { Promote the PDAC cells invasion, migration and tube formation through the downregulation by } \\
\text { activating the TGF- } \beta \text { signaling pathway to downregulate TGFBR3 }\end{array}$ & $(147)$ \\
\hline TAMs-EVs & Prostate cancer & MiR-95 & $\begin{array}{l}\text { Downregulate the downstream gene, JunB, to promote PCa cell proliferation, invasion, and } \\
\text { epithelial-mesenchymal transition }\end{array}$ & $(148)$ \\
\hline M2-EVs & EOC & MiR-221-3p & Suppress CDKN1B to enhance the proliferation and G1/S transition of EOC cells & (73) \\
\hline $\mathrm{M} \phi-E V s$ & EOC & MiR-223 & Induce cell drug resistance by activating PTEN-PI3K/AKT pathway & (149) \\
\hline $\begin{array}{l}\text { TWEAK-stimulated } \\
\text { macrophages-EVs }\end{array}$ & EOC & MiR-7 & $\begin{array}{l}\text { Inhibition of tumor metastasis and aggressiveness in vitro and in vivo via EGFR/AKT/ERK1/2 } \\
\text { signaling pathway }\end{array}$ & $(150)$ \\
\hline TAMs-EVs & EOC & MiR-146b-5p & Inhibit the HUVECs migration by activating TRAF6/NF-кB/MMP2 pathway. & $(151)$ \\
\hline TAMs-EVs & EOC & $\begin{array}{l}\text { MiR-29a-3p, } \\
\text { MiR-21-5p }\end{array}$ & Suppress STAT3 expression and regulate the ratio of Treg/Th17 & $(152)$ \\
\hline M2-EVs & $\begin{array}{l}\text { Breast cancer } \\
\text { cells }\end{array}$ & MiR-223 & Target the Mef2c- $\beta$-catenin pathway and promote breast cancer cell invasion & (99) \\
\hline $\mathrm{M} \phi-\mathrm{EV} s$ & $\mathrm{HCC}$ & $\begin{array}{l}\text { MiR-142, } \\
\text { MiR-223 }\end{array}$ & Inhibit HCC proliferation through suppressing STMN1 and IGF-1R expression & (153) \\
\hline TAMs-EVs & $\mathrm{HCC}$ & MiR-125a/b & Suppress cell proliferation and stem cell properties by targeting CD90 & $(154)$ \\
\hline $\mathrm{M} \phi-E V s$ & $\mathrm{HCC}$ & MiR-92a-2-5p & $\begin{array}{l}\text { Suppress androgen receptor translation, modify the PHLPP/p-AKT/ } \beta \text {-catenin signaling to } \\
\text { increase liver cancer cells invasion }\end{array}$ & $(74)$ \\
\hline M2-EVs & $\mathrm{HCC}$ & MiR-149-5p & Promote the invasion and migration of HCC by increasing MMP9 pathway & $(155)$ \\
\hline TAMs-EVs & PDAC & MiR-365 & $\begin{array}{l}\text { Upregulate pyrimidine metabolism and } \\
\text { increase NTP levels in cancer cells, upregulating CDA to promote gemcitabine resistance }\end{array}$ & $(156)$ \\
\hline TAMs-EVs & $\begin{array}{l}\text { Neuroblastoma } \\
\text { cells }\end{array}$ & MiR-155 & Downregulate TERF1 expression to increase CDDP resistance both in vitro and in vivo & $(157)$ \\
\hline M2-EVs & Glioma cells & MiR-21 & $\begin{array}{l}\text { Promote migration, proliferation and invasion, suppress apoptosis of glioma cells by reducing } \\
\text { PEG3 expression }\end{array}$ & $(158)$ \\
\hline M2-EVs & $\begin{array}{l}\text { Bladder } \\
\text { carcinogenesis }\end{array}$ & MiR-21 & Promote cell migration and induce cell CDDP resistance & (159) \\
\hline M2-EVs & $\begin{array}{l}\text { Esophageal } \\
\text { Cancer }\end{array}$ & MiR-26a & Regulate the impacts of overexpressed AFAP1-AS1 on cell migration and invasion & $(160)$ \\
\hline
\end{tabular}

promote hepatocellular carcinoma tumor migration by mediating the intercellular transfer of $\alpha \mathrm{M} \beta 2$ (CD11b/ CD18) (24).

Recently, it was found that EVs contain damaged DNA from the nucleus and mitochondria, regulating tumor immunity via paracrine and activated cytoplasmic DNA sensor pathways and in specific immune cell subpopulations (164). After chemotherapy, exposing $\mathrm{M} \varphi$ to apoptotic breast cancer cells causes higher levels of IL- 6 to be released and delivered to cancer cells via increased phosphorylation of STAT3, promoting the proliferation and metastasis of the cells (8). Furthermore, $\mathrm{M \varphi -}$ EVs may synthesize proteins such as thromboxane and thromboxane B2 (163). However, it is unclear whether they contain functional endogenous DNA. In oral squamous cell carcinoma, THP-1-derived EVs and native human $\mathrm{M} \varphi$-derived EVs have been shown to activate the AKT/GSK-3 $\beta$ signaling pathway, reducing the proliferative effects of 5 -FU and cis -diamminedichloroplatinum (CDDP) and the apoptosis of OSC-4 cells (165).

Metabolic reprogramming, an essential hallmark of malignancy, is regulated by the microenvironment. TAMderived EVs enhance aerobic metastasis and the anti-apoptotic ability of carcinoma cells by transporting a myeloid-specific long non-coding RNA and HIF-1 $\alpha$-stabilizing long non-coding RNA (HISLA) (166). HILSA inhibits the hydroxylation and degradation of HIF-1 $\alpha$, whereas carboxylic acid secreted from growing glycolytic cells upregulates HISLA in TAMs, constituting a feed-forward loop between TAMs and growing cells. Thus, HISLA inhibits metastasis and chemoresistance in carcinoma in vivo (166). This suggests that EVs-mediated metabolic reprogramming plays an important role in the intercellular communication between immune and tumor cells. Azambuja et al. proposed that glioblastoma-derived EVs reprogram $\mathrm{M} 1 \mathrm{M} \varphi$ into $\mathrm{TAMs}$ and promote the pro-tumor 
functions of $\mathrm{M} 2 \mathrm{M} \varphi$, while these GEV-reprogrammed TAM-EVs promote glioblastoma cell migration and proliferation (27).

In summary, because $\mathrm{M} \varphi$ are sensitive to microenvironmental stimuli, the composition of their secreted EVs in different disease models change as the $\mathrm{M} \varphi$ themselves are altered.

\section{Pulmonary Disease}

Idiopathic pulmonary fibrosis (IPF) is an intermittent and chronic fibrotic lung disease associated with inflammatory immune damage, caused primarily by chronic alveolar epithelial injury and dysregulated wound healing due to abnormal proliferation of fibroblasts (167). The expression of miR-142-3p is markedly increased in the sputum and plasma of IPF patients, and M $\varphi$-EVs reduce the expression of TGF $\beta$ receptor 1 by transporting $\mathrm{miR}-142-3 \mathrm{p}$, suppressing the progression of pulmonary fibrosis (50). Antifibrotic miRNA delivery in the lung can effectively prevent pulmonary fibrosis and provide new therapeutic avenues for the treatment of IPF. In addition, M2-EVs may transport miR-328, facilitating the proliferation of pulmonary interstitial fibroblasts via family with sequence similarity 13, member A (61).

Another pulmonary fibrosis-related disease is silicosis, which is caused by long-term inhalation of large amounts of free silica dust and is characterized by extensive nodular fibrosis of the lungs (168). EVs have been isolated from silica-exposed $\mathrm{M} \varphi$ and found to induce the proliferation of myofibroblasts and fibroblasts and increase their expression levels of SPP1 (36). They also induce the overproduction of proinflammatory cytokines and promote myofibroblast activation in an endoplasmic reticulum stress-dependent manner (30).

In acute lung injury, $\mathrm{M} \varphi$-EVs in alveolar lavage fluid release various pro-inflammatory factors mainly during the early stages of damage; this activates neutrophils to produce IL-10, which might be responsible for polarizing $\mathrm{M} \varphi$ to $\mathrm{M} 2 \mathrm{c}$, leading to postacute lung injury fibrosis (169).

Asthma, a chronic respiratory disease, is characterized by inflammation and hyperresponsiveness of the airways (170). M2EVs deliver miR-370 to reduce cell apoptosis and relieve inflammation by suppressing the FGF1/MAPK/STAT1 axis (70). M2-EVs have also been found to upregulate AGAP2-AS1 and NOTCH2 expression and downregulate miR-296 expression to strengthen the radioresistance of lung cancer cells (44).

\section{Gastrointestinal Disease}

Chronic inflammation influences the development of spasmolytic polypeptide-expressing metaplasia (171), and deoxycholic acid (DCA) enhances the expression of enteral metaplasia markers (172). Xu et al. cocultured mouse stomachic organoids with DCA treated macrophage-derived $\operatorname{EVs}(\mathrm{DCA}-\mathrm{M} \varphi-\mathrm{EV} s)$, and the data revealed that the expression of SPEM marker proteins TFF2, GSII, SPEM-related cistron Wfdc2, Olfm 4 and Cftr were considerably inflated when $72 \mathrm{~h}$ cocultured (172). In addition, miR-30a-5p enriched in $\mathrm{M} \varphi$-EVs derived from DCA promotes intestinal metaplasia and inhibits the proliferation of human gastric cancer cells by targeting forkhead box D1 (54). These results suggest that $\mathrm{M} \varphi$-EVs may mediate intercellular communication in the DCA microenvironment and promote the progression of spasmolytic polypeptide-expressing metaplasia, providing a new target for treating gastric intestinal metaplasia.

Chronic intestinal inflammation may eventually lead to inflammatory bowel disease (173). To assess the effects of $\mathrm{M \varphi}$ derived EVs on inflammatory bowel disease, Yang et al. isolated EVs from the $\mathrm{M} 2 \mathrm{aM} \varphi, \mathrm{M} 2 \mathrm{bM} \varphi$, and $\mathrm{M} 2 \mathrm{cM} \varphi$ phenotypes and established a dextran sulfate sodium-induced colitis model in mice (12). Treating the mice with M2-EVs improved colon length. Furthermore, compared with EVs derived from $\mathrm{M} 2 \mathrm{aM} \varphi$ and $\mathrm{M} 2 \mathrm{cM} \varphi, \mathrm{M} 2 \mathrm{bM} \varphi$-derived EVs were more effective. These EVs may interact with CCR8 by releasing the CCL1 chemokine, thereby increasing the expression of IL-4 and number of regulatory $\mathrm{T}$ cells to promote the Th2 immune response (12).

\section{POTENTIAL THERAPEUTIC STRATEGIES}

EVs are considered a promising tool for immunotherapy, drug delivery, and targeted therapy. Furthermore, some strategies were proposed to strengthen the therapeutic capabilities and broaden the applications of EVs. Recent applications are discussed below (Table 3).

\section{$\mathrm{M} \varphi-E V s$ as a Drug Candidate}

As messengers carrying genes, proteins, and other biomolecules, EVs mediate communication in cells and have therapeutic functions. Kang et al. (25) applied M0-EVs, M1-EVs, and M2EVs to rat calvaria defects; M2-EVs carrying miR-378a increased the expression of the mesenchymal stem cell osteoinductive genes BMP2 and BMP9 in the bone repair process to promote bone regeneration (100). Furthermore, proteomic profiling analysis of the protein composition of LPS-treated $\mathrm{M} \varphi$-EVs (L-M $\varphi$-EVs) revealed that among 341 upregulated proteins in L-M $\varphi$-EVs, 22 are involved in the NOD-like receptor signaling pathway. After L$\mathrm{M} \varphi$-EVs were taken up by hepatocytes, NLRP3 was activated, which promoted acute liver injury (25). In ischemic stroke, microglia are converted into M1 phenotypes that release proinflammatory mediators, promoting neuronal apoptosis and brain injury (174). L-M $\varphi$-EVs suppress inflammation, enhance microglial M2 polarization (which induces neuroprotection), and reduce the brain infarct volume in vivo after ischemic stroke (174). The miRNAs in $\mathrm{M} \varphi$-EVs are involved in different pathways to regulate the development of disease(Qian et al.; 7, 133). In chronic liver disease, $\mathrm{L}-\mathrm{M} \varphi-\mathrm{EV}$ s have been shown to promote the proliferation and activation of hepatic stellate cells by enriching miR-103-3p and targeting Krüppel-like factor 4 (55). IL-4-treated $\mathrm{M} \varphi$-EVs transported anti-inflammatory miR-99a/146b/378a to inhibit inflammation by targeting NF- $\kappa \mathrm{B}$ and TNF- $\alpha$ signaling, leading to delayed development of AS (49).

In addition, $\mathrm{M} \varphi$-EVs may have therapeutic functions via $\mathrm{M} \varphi$ reprogramming. For example, M2-EVs promote wound healing by enhancing proliferation, angiogenesis, and collagen deposition (132), which suggests that $\mathrm{M} \varphi$ phenotype reprogramming could provide valuable therapeutic options for the treatment of inflammationrelated diseases. M1-EVs can also potentially be used to repolarize $\mathrm{M} 2$ to $\mathrm{M} 1 \mathrm{M} \varphi$ that secrete pro-inflammatory cytokines, have antitumor effects, and decrease tumor growth (175). Similarly, 
TABLE 3 | The applications of M $\varphi$-EVs.

\begin{tabular}{|c|c|c|c|c|c|}
\hline $\begin{array}{l}\text { EVs } \\
\text { Source }\end{array}$ & $\begin{array}{l}\text { Precondition of } \\
\text { Macrophages }\end{array}$ & EVs Treatment & Disease model & Application & Reference \\
\hline $\begin{array}{l}\text { M2- } \\
\text { EVs }\end{array}$ & - & - & Calvaria defects & Promote bone regeneration & $(100)$ \\
\hline $\mathrm{M} \phi-\mathrm{EV} s$ & Induced by LPS & - & Acute liver injury & $\begin{array}{l}\text { Be involved in the activation of NLRP3 and NOD-like receptor } \\
\text { signaling pathway }\end{array}$ & (25) \\
\hline $\mathrm{M \phi}-\mathrm{EV} \mathrm{s}$ & Induced by LPS & - & Ischemic stroke & Induce neuroprotection, and reduce the brain infarct & $(174)$ \\
\hline M $\phi-E V s$ & Induced by LPS & - & $\begin{array}{l}\text { Chronic liver } \\
\text { diseases }\end{array}$ & Promote hepatic stellate cells proliferation and activation & $(55)$ \\
\hline $\mathrm{M \phi}-\mathrm{EV} \mathrm{s}$ & Treated with IL-4 & - & AS & Reduce the areas of necrotic lesion & (49) \\
\hline $\begin{array}{l}\text { M2- } \\
\text { EVs }\end{array}$ & - & - & Cutaneous wound & Promote wound healing & $(132)$ \\
\hline $\begin{array}{l}\text { M1- } \\
\text { EVs }\end{array}$ & - & - & $\begin{array}{l}\text { Colorectal } \\
\text { carcinoma }\end{array}$ & $\begin{array}{l}\text { Enhance the anti-tumor effect of checkpoint inhibitors (anti-PD- } \\
\text { L1 antibody) in cancer therapy }\end{array}$ & $(175)$ \\
\hline M $\phi-E V s$ & - & Loaded with Doxorubicin & Pancreatic cancer & Deliver Doxorubicin to perform anti-tumor efficacy & $(176)$ \\
\hline $\begin{array}{l}\text { M1- } \\
\text { EVs }\end{array}$ & - & Loaded with CDDP & Ovarian cancer & Increase cytotoxicity in drug-resistant by loaded with CDDP & $(177)$ \\
\hline $\mathrm{M} \phi-E V s$ & $\begin{array}{l}\text { Infected by M. } \\
\text { bovis BCG }\end{array}$ & - & $\begin{array}{l}\text { M. tuberculosis } \\
\text { infection. }\end{array}$ & $\begin{array}{l}\text { Induce a CD } 4^{+} \text {and } \mathrm{CD} 8^{+} \text {memory } \mathrm{T} \text { cell response and stimulate } \\
\mathrm{DC} \text { activation }\end{array}$ & $(178)$ \\
\hline $\begin{array}{l}\text { M1- } \\
\text { EVs }\end{array}$ & - & - & Melanoma & $\begin{array}{l}\text { Enhance the efficacy of peptide vaccine, the cytotoxic T cell } \\
\text { immune response and present anti-tumor effect }\end{array}$ & $(179)$ \\
\hline $\begin{array}{l}\text { M2- } \\
\text { EVs }\end{array}$ & - & - & Fracture & Induce bone mesenchymal stem cells osteogenic differentiation & $(57)$ \\
\hline $\mathrm{M \phi}-\mathrm{EV} \mathrm{s}$ & - & - & Inflammation brain & Deliver the brain derived neurotrophic factor to the brain & $(40)$ \\
\hline $\mathrm{M \phi}$-EVs & - & Loaded with catalase & $\begin{array}{l}\text { Parkinson's } \\
\text { disease }\end{array}$ & $\begin{array}{l}\text { Deliver catalase to against oxidative stress, decrease brain } \\
\text { inflammation and increase neuronal survival }\end{array}$ & $(180)$ \\
\hline $\mathrm{M \phi}-\mathrm{EV} s$ & - & Loaded with Edaravone & Stroke & $\begin{array}{l}\text { Improve the bioavailability of Edaravone and strengthen the } \\
\text { neuroprotective effects }\end{array}$ & $(13)$ \\
\hline $\mathrm{M} \phi-\mathrm{EV} s$ & - & Loaded with baicalin & Ischemic stroke & $\begin{array}{l}\text { Improve the solubility of Baicalin, brain targeting ability and } \\
\text { present neuroprotection }\end{array}$ & $(181)$ \\
\hline $\mathrm{M} \phi-\mathrm{EV} s$ & - & Loaded with PTX & Lung carcinoma & $\begin{array}{l}\text { Deliver PTX to overcome multiple drug resistance and assess } \\
\text { anti-cancer therapy }\end{array}$ & $(182)$ \\
\hline $\begin{array}{l}\text { M2- } \\
\text { EVs }\end{array}$ & - & Loaded with Berberine & Spinal cord injury & Deliver drugs to the injured spinal cord & $(183)$ \\
\hline $\mathrm{M} \phi-E V s$ & - & $\begin{array}{l}\text { Engeneered with AA-PEG vector } \\
\text { moiety }\end{array}$ & $\begin{array}{l}\text { Pulmonary } \\
\text { metastases }\end{array}$ & Improve the loading capacity and therapeutic effects & $(184)$ \\
\hline $\begin{array}{l}\text { M1- } \\
\text { EVs }\end{array}$ & - & $\begin{array}{l}\text { Modified with anti-CD47 and anti- } \\
\operatorname{SIRP} \alpha\end{array}$ & $\begin{array}{l}\text { Acidic tumor } \\
\text { microenvironment, }\end{array}$ & $\begin{array}{l}\text { Target tumors more effectively, reprogram } \mathrm{M} 2 \mathrm{M} \varphi \text { to } \mathrm{M} 1 \mathrm{M} \varphi \text {, } \\
\text { exert anti-tumor function }\end{array}$ & $(185)$ \\
\hline$M \phi-E V s$ & - & Loaded with Biomimetic silibinin & $\begin{array}{l}\text { Alzheimer's } \\
\text { disease }\end{array}$ & $\begin{array}{l}\text { Inhibit astrocytes activation and alleviate astrocyte inflammation- } \\
\text { mediated neuronal damage }\end{array}$ & $(186)$ \\
\hline $\begin{array}{l}\text { Mф- } \\
\text { A15 } \\
\text {-EVs }\end{array}$ & $\begin{array}{l}\text { Stimulated by } \\
\text { phorbol 12- } \\
\text { myristate 13- } \\
\text { acetate }\end{array}$ & $\begin{array}{l}\text { Loaded with Doxorubicin } \\
\text { hydrochloride and co-incubated } \\
\text { cholesterol-modified mi159 }\end{array}$ & $\begin{array}{l}\text { Triple-negative } \\
\text { breast cancer }\end{array}$ & $\begin{array}{l}\text { Co-deliver cholesterol-modified miRNA and chemotherapeutic } \\
\text { drugs, perform more specific and robust targeting properties, } \\
\text { and suppress tumor growth }\end{array}$ & $(187)$ \\
\hline M $\phi$-EVs & - & $\begin{array}{l}\text { Coated with poly (lactic-co-glycolic } \\
\text { acid) }\end{array}$ & $\begin{array}{l}\text { Triple-negative } \\
\text { breast cancer }\end{array}$ & $\begin{array}{l}\text { Improve the tumor-targeting, the cellular uptaking and the } \\
\text { antitumor efficacy }\end{array}$ & (188) \\
\hline $\begin{array}{l}\text { M2- } \\
\text { EVs }\end{array}$ & - & $\begin{array}{l}\text { Modified with hexyl 5- } \\
\text { aminolevulinate hydrochloride }\end{array}$ & AS & Enhance the anti-inflammatory effect and relieve AS & (189) \\
\hline $\begin{array}{l}\text { M1- } \\
\text { EVs }\end{array}$ & - & Loaded with PTX & Breast cancer & Deliver PTX to enhance the anti-tumor activity & $(190)$ \\
\hline
\end{tabular}

PTX, paclitaxel; AS, Atherosclerosis; AA-PEG, Aminoethylanisamide-polyethylene glycol; CDDP, Cisplatin; DC, Dendritic cells.

M1-EVs transport miR-130 and miR-33 to exert antitumor effects in breast cancer by polarizing $\mathrm{M} \varphi$ from the $\mathrm{M} 2$ to $\mathrm{M} 1$ phenotype (69).

\section{M $\varphi$-EVs as Drug-Delivery Systems}

Many nanocarrier delivery systems have been designed to improve the efficacy of drugs, and EVs have the following advantages compared with other nanocarrier delivery systems: they transport a variety of endogenous biomolecules, and they are biocompatible, naturally targeted, and small enough to escape the clearance effect of the mononuclear phagocyte system $(191,192)$. Kanchanapally et al. (176) obtained EVs from different cells, including pancreatic cancer cells, pancreatic stellate cells, and $\mathrm{M} \varphi$ loaded with doxorubicin (DOX), and compared their antitumor effects. $M \varphi$-EVs loaded with DOX showed the highest antitumor efficiency followed by pancreatic stellate and pancreatic cancer cells. Zhang et al. isolated EVs from mononuclear $\mathrm{M} 1 \mathrm{M} \varphi$ and $\mathrm{M} 2 \mathrm{M} \varphi$ from umbilical cord blood and loaded them with CDDP; compared with the M2-EVs, M1-EVs showed increased cytotoxicity in drugresistant A2780/DDP cells, suggesting that M1-EVs are a potential drug carrier in drug-resistant microenvironments (177).

The inability to cross the blood brain barrier (BBB) limits the application of $98 \%$ of therapeutic agents used for the treatment of 
CNS-related disorders (193). Recently, Yuan et al. (40) discovered that $\mathrm{M} \varphi$-EVs can cross the $\mathrm{BBB}$ and move into brain microvessel endothelial cells via integrin white corpuscle function-associated matter 1, living thing adhesion molecule 1, and carbohydratebinding C-type glycoprotein receptors. That study further confirmed that intravenously injected $\mathrm{M} \varphi-\mathrm{EV}$ s crossed the BBB and transported brain-derived neurotrophic factor to the brain (40). A novel EVs-based formulation for catalase delivery in Parkinson's disease patients was found to have neuroprotective effects against oxidative stress by inactivating ROS, decreasing brain inflammation, and increasing neuronal survival in vivo (180). That study provided a new theoretical basis for the development of other EVs-based drug-delivery systems for the treatment of CNS diseases, as well as an experimental basis for the in-depth study of the mechanisms involved in EV passage through the BBB. Silibinin, an antioxidant with poor brain targeting, has been applied to improve behavior and cognition in Parkinson's patients. Huo et al. loaded $\mathrm{M} \varphi$-EVs with silibinin to improve its targeting capacity and released the silibinin to suppress astrocyte activation and relieve neuronal damage after crossing the BBB (186). Edaravone (Edv) delays neuronal death caused by acute cerebral infarction. Li et al. (13) prepared $\mathrm{M} \varphi$-EVs loaded with Edv, applied them to a rat model with permanent middle cerebral artery occlusion, and found that they notably improved bioavailability and prolonged the half-life of Edv. In addition, using these Edv-loaded $\mathrm{M} \varphi$-EVs, it was easier to target Edv to the ischemic side, and the treatment decreased neuronal death and promoted microglia M2 polarization in vivo.

Spinal cord injury severely damages the CNS. Gao et al. (183) developed an M2-EV-loaded berberine drug-delivery system that effectively prolonged the duration of berberine and improved its targeting capacity. In addition, it had anti-inflammatory and antiapoptotic effects by repolarizing M $\varphi$ from the M1 to M2 phenotype. $\mathrm{M} \varphi$-EVs loaded with baicalin have been found to ameliorate the solubility and brain-targeting ability of baicalin, leading to significant neuroprotection in patients with ischemic stroke (181).

\section{Application of Engineered $\mathrm{M} \varphi$-EVs}

Through genetic and chemical modifications, engineered EVs can enhance EVs targeting and therapeutic effects in cancer treatment (194). For example, M $\varphi$ loaded with paclitaxel show significant loading capacity, sustainable drug release, a profound capacity for accumulation in resistant cancer cells, and high cytotoxicity (182). $\mathrm{M} \varphi$ loaded with paclitaxel and aminoethylbenzamide-polyethylene glycol readily accumulate in cancer cells and have a higher therapeutic effect in vivo compared with non-vectorized $\mathrm{M} \varphi$ loaded with paclitaxel (184). M1-EVs tagged with anti-CD47 and antiSIRP $\alpha$ using a $\mathrm{pH}$-sensitive linker effectively target tumors, block $\mathrm{SIRP} \alpha$ and $\mathrm{CD} 47$, and reprogram $\mathrm{M} 2 \mathrm{M} \varphi$ to $\mathrm{M} 1 \mathrm{M} \varphi$, thereby exerting antitumor functions (185). Gong et al. stimulated THP-1 cells with phorbol 12-myristate 13-acetate to generate target-specific A15 EVs, packing Dox into them to codeliver cholesterol-modified miRNAs and chemotherapeutic drugs into triple-negative breast cancer cells; the system showed specific and robust targeting capabilities and suppressed tumor growth in vivo (187). To improve triple-negative breast cancer targetability, Li et al. (188) modified the surface of $\mathrm{M} \varphi$ EVs with a peptide to target mesenchymal-epithelial transition factor and developed a $\mathrm{M} \varphi$-EV-coated poly (lactic-co-glycolic acid) nanoplatform, which improved the efficiency of cellular uptake and the antitumor effects of DOX. Wu et al. (189) electroporated M2-EVs with FDA-approved hexyl 5-aminolevulinate hydrochloride, which produced anti-inflammatory carbon monoxide and bilirubin and further enhanced the anti-inflammatory effect by binding to surfaceexpressed chemokine receptors and releasing anti-inflammatory cytokines; they also relieved AS.

Modification of EVs may enhance their release of anticancer drugs and their antitumor effects by releasing pro-inflammatory Th1 cytokines. For example, M1-EV nano-formulation-loaded paclitaxel creates a pro-inflammatory environment that improves antitumor activity via the caspase-3 signaling pathway and exhibits antitumor effects in vivo (190).

In summary, $\mathrm{M} \varphi$-EVs have similar targeting and regulatory abilities as those of $\mathrm{M} \varphi$. Thus, the advantages of $\mathrm{M} \varphi$-EVs in terms of their nanometer size, cellular targeting, and low immunogenicity make them excellent candidates for nextgeneration drug-delivery systems.

\section{CONCLUSION AND PERSPECTIVES}

There are some unresolved issues regarding $\mathrm{M} \varphi$-EVs, such as the efficiency of their isolation and purification (195). To address this, Jang et al. (196) created bioinspired exosome-mimetic nanovesicles by breaking down monocytes or $\mathrm{M} \varphi$ and found that they had similar functional properties as EVs, with 100-fold better isolation and purification efficiency; they also induced TNF$\alpha$-stimulated endothelial cell death and showed antitumor activity in vivo. Choo et al. (175) prepared exosome-mimetic nanovesicles derived from $\mathrm{M} 1 \mathrm{M} \varphi$, which effectively repolarized $\mathrm{M} 2 \mathrm{M} \varphi$ to $\mathrm{M} 1 \mathrm{M} \varphi$ and promoted the antitumor efficacy of programmed death ligand 1. EVs have been characterized based on protein content $(23,197)$. However, the molecular hallmarks specifically distinguishing each EV subtype remain unclear (23). This issue should be further explored and addressed.

Overall, studies have shown that $\mathrm{M} \varphi$-EV-based immunomodulation strategies are effective treatments for various pathological conditions. In the future, more studies are needed to further investigate $\mathrm{M} \varphi$-EV-related mechanisms and develop $\mathrm{M} \varphi$-EVs based on therapeutic strategies.

\section{AUTHOR CONTRIBUTIONS}

QY and YHZ initiated the project, made suggestions and revised the article. YX searched the database and wrote the first draft of the manuscript. XS, YD, MW, and YMZ revised and finalized the manuscript. All authors contributed to the article and approved the submitted version.

\section{FUNDING}

This work was supported by National Natural Science Foundation of China (82072435, 81871782), Tianjin Science Fund for Distinguished Young Scholars (18JCJQJC47900), and Tianjin Science and Technology Program (20JCYBJC01440). 


\section{REFERENCES}

1. Liu J, Wu F, Zhou H. Macrophage-Derived Exosomes in Cancers: Biogenesis, Functions and Therapeutic Applications. Immunol Lett (2020) 227:102-8. doi: 10.1016/j.imlet.2020.08.003

2. Wu P, Zhang B, Ocansey DKW, Xu W, Qian H. Extracellular Vesicles: A Bright Star of Nanomedicine. Biomaterials (2021) 269:120467. doi: 10.1016/ j.biomaterials.2020.120467

3. Yánez-Mo M, Siljander PR, Andreu Z, Zavec AB, BorrÃ s FE, Buzas EI, et al. Biological Properties of Extracellular Vesicles and Their Physiological Functions. J Extracell Vesicles (2015) 4:27066. doi: 10.3402/jev.v4.27066

4. Kalluri R, LeBleu VS. The Biology, Function, and Biomedical Applications of Exosomes. Science (2020) 367(6478):eaau6977. doi: 10.1126/science.aau6977

5. Pan BT, Teng K, Wu C, Adam M, Johnstone RM. Electron Microscopic Evidence for Externalization of the Transferrin Receptor in Vesicular Form in Sheep Reticulocytes. J Cell Biol (1985) 101(3):942-8. doi: 10.1083/ jcb.101.3.942

6. Liu Y, Wang Y, Lv Q, Li X. Exosomes: From Garbage Bins to Translational Medicine. Int J Pharm (2020) 583:119333. doi: 10.1016/ j.ijpharm.2020.119333

7. Shi ZY, Yang XX, Malichewe C, Li YS, Guo XL. Exosomal microRNAsMediated Intercellular Communication and Exosome-Based Cancer Treatment. Int J Biol Macromol (2020) 158:530-41. doi: 10.1016/ j.ijbiomac.2020.04.228

8. Yu X, Zhang Q, Zhang X, Han Q, Li H, Mao Y, et al. Exosomes From Macrophages Exposed to Apoptotic Breast Cancer Cells Promote Breast Cancer Proliferation and Metastasis. J Cancer (2019) 10(13):2892-906. doi: $10.7150 /$ jca.31241

9. Lee KS, Lee J, Lee P, Kim CU, Kim DJ, Jeong YJ, et al. Exosomes Released From Shiga Toxin 2a-Treated Human Macrophages Modulate Inflammatory Responses and Induce Cell Death in Toxin Receptor Expressing Human Cells. Cell Microbiol (2020) 22(11):e13249. doi: $10.1111 / \mathrm{cmi} .13249$

10. Zheng PM, Gao HJ, Li JM, Zhang P, Li G. [Effect of Exosome-Derived miR223 From Macrophages on the Metastasis of Gastric Cancer Cells]. Zhonghua Yi Xue Za Zhi (2020) 100(22):1750-5. doi: 10.3760/ cma.j.cn112137-20200425-01309

11. Lin J, Li J, Huang B, Liu J, Chen X, Chen XM, et al. Exosomes: Novel Biomarkers for Clinical Diagnosis. ScientificWorldJournal (2015) 2015:657086. doi: 10.1155/2015/657086

12. Yang R, Liao Y, Wang L, He P, Hu Y, Yuan D, et al. Exosomes Derived From M2b Macrophages Attenuate DSS-Induced Colitis. Front Immunol (2019) 10:2346. doi: 10.3389/fimmu.2019.02346

13. Li F, Zhao L, Shi Y, Liang J. Edaravone-Loaded Macrophage-Derived Exosomes Enhance Neuroprotection in the Rat Permanent Middle Cerebral Artery Occlusion Model of Stroke. Mol Pharm (2020) 17 (9):3192-201. doi: 10.1021/acs.molpharmaceut.0c00245

14. Porcuna J, MenÃ@ndez-GutiÃ@rrez MP, Ricote M. Molecular Control of Tissue-Resident Macrophage Identity by Nuclear Receptors. Curr Opin Pharmacol (2020) 53:27-34. doi: 10.1016/j.coph.2020.04.001

15. Orecchioni M, Ghosheh Y, Pramod AB, Ley K. Macrophage Polarization: Different Gene Signatures in M1(LPS+) vs. Classically and M2(LPS-) vs. Alternatively Activated Macrophages. Front Immunol (2019) 10:1084. doi: 10.3389/fimmu.2019.01084

16. Shapouri-Moghaddam A, Mohammadian S, Vazini H, Taghadosi M, Esmaeili SA, Mardani F, et al. Macrophage Plasticity, Polarization, and Function in Health and Disease. J Cell Physiol (2018) 233(9):6425-40. doi: $10.1002 /$ jcp. 26429

17. Du C, Bhatia M, Tang SC, Zhang M, Steiner T. Mediators of Inflammation: Inflammation in Cancer, Chronic Diseases, and Wound Healing. Mediators Inflamm (2015) 2015:570653. doi: 10.1155/2015/570653

18. Schottenfeld D, Beebe-Dimmer J. Chronic Inflammation: A Common and Important Factor in the Pathogenesis of Neoplasia. CA Cancer J Clin (2006) 56(2):69-83. doi: 10.3322/canjclin.56.2.69

19. Bauer UE, Briss PA, Goodman RA, Bowman BA. Prevention of Chronic Disease in the 21st Century: Elimination of the Leading Preventable Causes of Premature Death and Disability in the USA. Lancet (2014) 384(9937):4552. doi: 10.1016/s0140-6736(14)60648-6
20. Hotamisligil GS. Inflammation and Metabolic Disorders. Nature (2006) 444 (7121):860-7. doi: 10.1038/nature05485

21. Miyamoto T, Carrero JJ, Stenvinkel P. Inflammation as a Risk Factor and Target for Therapy in Chronic Kidney Disease. Curr Opin Nephrol Hypertens (2011) 20(6):662-8. doi: 10.1097/MNH.0b013e32834ad504

22. Scrivo R, Vasile M, Bartosiewicz I, Valesini G. Inflammation as "Common Soil" of the Multifactorial Diseases. Autoimmun Rev (2011) 10(7):369-74. doi: 10.1016/j.autrev.2010.12.006

23. ThÃ@ry C, Witwer KW, Aikawa E, Alcaraz MJ, Anderson JD, Andriantsitohaina $\mathrm{R}$, et al. Minimal Information for Studies of Extracellular Vesicles 2018 (MISEV2018): A Position Statement of the International Society for Extracellular Vesicles and Update of the MISEV2014 Guidelines. J Extracellular Vesicles (2018) 7(1):15357501535750. doi: 10.1080/20013078.2018.1535750

24. Wu J, Gao W, Tang Q, Yu Y, You W, Wu Z, et al. M2 MacrophageDerived Exosomes Facilitate HCC Metastasis by Transferring $\hat{\mathrm{I}} \pm(\mathrm{M}) \hat{\mathrm{I}}^{2}(2)$ Integrin to Tumor Cells. Hepatology (2021) 73(4):1365-80. doi: 10.1002/ hep.31432

25. Wang G, Jin S, Ling X, Li Y, Hu Y, Zhang Y, et al. Proteomic Profiling of LPS-Induced Macrophage-Derived Exosomes Indicates Their Involvement in Acute Liver Injury. Proteomics (2019) 19(3):e1800274. doi: 10.1002/ pmic.201800274

26. Zhang $Y$, Liu F, Yuan $Y$, Jin $C$, Chang $C$, Zhu $Y$, et al. InflammasomeDerived Exosomes Activate NF-I $\hat{I}^{\circ} B$ Signaling in Macrophages. J Proteome Res (2017) 16(1):170-8. doi: 10.1021/acs.jproteome.6b00599

27. Azambuja JH, Ludwig N, Yerneni SS, Braganhol E, Whiteside TL. Arginase1+ Exosomes From Reprogrammed Macrophages Promote Glioblastoma Progression. Int J Mol Sci (2020) 21(11):3990. doi: 10.3390/ijms21113990

28. Sun NN, Zhang Y, Huang WH, Zheng BJ, Jin SY, Li X, et al. Macrophage Exosomes Transfer Angiotensin II Type 1 Receptor to Lung Fibroblasts Mediating Bleomycin-Induced Pulmonary Fibrosis. Chin Med J (Engl) (2021) 134(18):2175-85. doi: 10.1097/cm9.0000000000001605

29. Haque S, Sinha N, Ranjit S, Midde NM, Kashanchi F, Kumar S. MonocyteDerived Exosomes Upon Exposure to Cigarette Smoke Condensate Alter Their Characteristics and Show Protective Effect Against Cytotoxicity and HIV-1 Replication. Sci Rep (2017) 7(1):16120. doi: 10.1038/s41598-01716301-9

30. Qin X, Lin X, Liu L, Li Y, Li X, Deng Z, et al. Macrophage-Derived Exosomes Mediate Silica-Induced Pulmonary Fibrosis by Activating Fibroblast in an Endoplasmic Reticulum Stress-Dependent Manner. J Cell Mol Med (2021) 25(9):4466-77. doi: $10.1111 / \mathrm{jcmm} .16524$

31. Zhu QJ, Zhu M, Xu XX, Meng XM, Wu YG. Exosomes From High GlucoseTreated Macrophages Activate Glomerular Mesangial Cells via TGF-I ${ }^{2} 1 /$ Smad3 Pathway In Vivo and In Vitro. FASEB J (2019) 33(8):9279-90. doi: 10.1096/fj.201802427RRR

32. Huang C, Huang Y, Zhou Y, Nie W, Pu X, Xu X, et al. Exosomes Derived From Oxidized LDL-Stimulated Macrophages Attenuate the Growth and Tube Formation of Endothelial Cells. Mol Med Rep (2018) 17(3):4605-10. doi: $10.3892 / \mathrm{mmr} .2018 .8380$

33. Lee HD, Kim YH, Kim DS. Exosomes Derived From Human Macrophages Suppress Endothelial Cell Migration by Controlling Integrin Trafficking. Eur J Immunol (2014) 44(4):1156-69. doi: 10.1002/eji.201343660

34. Lee HD, Koo BH, Kim YH, Jeon OH, Kim DS. Exosome Release of ADAM15 and the Functional Implications of Human Macrophage-Derived ADAM15 Exosomes. FASEB J (2012) 26(7):3084-95. doi: 10.1096/fj.11-201681

35. Yao Z, Jia X, Megger DA, Chen J, Liu Y, Li J, et al. Label-Free Proteomic Analysis of Exosomes Secreted From THP-1-Derived Macrophages Treated With IFN-Î \pm Identifies Antiviral Proteins Enriched in Exosomes. J Proteome Res (2019) 18(3):855-64. doi: 10.1021/acs.jproteome.8b00514

36. Huang R, Hao C, Wang D, Zhao Q, Li C, Wang C, et al. SPP1 Derived From Silica-Exposed Macrophage Exosomes Triggers Fibroblast Transdifferentiation. Toxicol Appl Pharmacol (2021) 422:115559. doi: 10.1016/j.taap.2021.115559

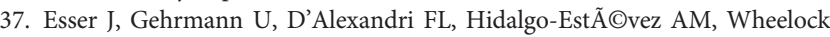
CE, Scheynius A, et al. Exosomes From Human Macrophages and Dendritic Cells Contain Enzymes for Leukotriene Biosynthesis and Promote Granulocyte Migration. J Allergy Clin Immunol (2010) 126(5):1032-1040, 1040.e1031-1034. doi: 10.1016/j.jaci.2010.06.039 
38. Hassani K, Olivier M. Immunomodulatory Impact of Leishmania-Induced Macrophage Exosomes: A Comparative Proteomic and Functional Analysis. PloS Negl Trop Dis (2013) 7(5):e2185. doi: 10.1371/journal.pntd.0002185

39. Singhto N, Kanlaya R, Nilnumkhum A, Thongboonkerd V. Roles of Macrophage Exosomes in Immune Response to Calcium Oxalate Monohydrate Crystals. Front Immunol (2018) 9:316. doi: 10.3389/ fimmu.2018.00316

40. Yuan D, Zhao Y, Banks WA, Bullock KM, Haney M, Batrakova E, et al. Macrophage Exosomes as Natural Nanocarriers for Protein Delivery to Inflamed Brain. Biomaterials (2017) 142:1-12. doi: 10.1016/ j.biomaterials.2017.07.011

41. Osada-Oka M, Shiota M, Izumi Y, Nishiyama M, Tanaka M, Yamaguchi T, et al. Macrophage-Derived Exosomes Induce Inflammatory Factors in Endothelial Cells Under Hypertensive Conditions. Hypertens Res (2017) 40(4):353-60. doi: 10.1038/hr.2016.163

42. Roth WW, Huang MB, Addae Konadu K, Powell MD, Bond VC. Micro RNA in Exosomes From HIV-Infected Macrophages. Int $J$ Environ Res Public Health (2015) 13(1):ijerph13010032. doi: 10.3390/ ijerph13010032

43. Yue Y, Huang S, Wu Z, Wang K, Li H, Hou J, et al. Characterization of mRNA Profiles of Exosomes From Diverse Forms of M2 Macrophages. BioMed Res Int (2020) 2020:1585306. doi: 10.1155/2020/1585306

44. Zhang F, Sang Y, Chen D, Wu X, Wang X, Yang W, et al. M2 MacrophageDerived Exosomal Long non-Coding RNA AGAP2-AS1 Enhances Radiotherapy Immunity in Lung Cancer by Reducing microRNA-296 and Elevating NOTCH2. Cell Death Dis (2021) 12(5):467. doi: 10.1038/s41419021-03700-0

45. Yin Z, Zhou Y, Ma T, Chen S, Shi N, Zou Y, et al. Down-Regulated lncRNA SBF2-AS1 in M2 Macrophage-Derived Exosomes Elevates miR-122-5p to Restrict XIAP, Thereby Limiting Pancreatic Cancer Development. J Cell Mol Med (2020) 24(9):5028-38. doi: 10.1111/jcmm.15125

46. Chen J, Zhou R, Liang Y, Fu X, Wang D, Wang C. Blockade of IncRNAASLNCS5088-Enriched Exosome Generation in M2 Macrophages by GW4869 Dampens the Effect of M2 Macrophages on Orchestrating Fibroblast Activation. FASEB J (2019) 33(11):12200-12. doi: 10.1096/ fj. 201901610

47. Lu J, Liu D, Tan Y, Deng F, Li R. M1 Macrophage Exosomes MiR-21a-5p Aggravates Inflammatory Bowel Disease Through Decreasing E-Cadherin and Subsequent ILC2 Activation. J Cell Mol Med (2021) 25(6):3041-50. doi: $10.1111 /$ jcmm. 16348

48. Liu S, Chen J, Shi J, Zhou W, Wang L, Fang W, et al. M1-Like MacrophageDerived Exosomes Suppress Angiogenesis and Exacerbate Cardiac Dysfunction in a Myocardial Infarction Microenvironment. Basic Res Cardiol (2020) 115(2):22. doi: 10.1007/s00395-020-0781-7

49. Bouchareychas L, Duong P, Covarrubias S, Alsop E, Phu TA, Chung A, et al. Macrophage Exosomes Resolve Atherosclerosis by Regulating Hematopoiesis and Inflammation via MicroRNA Cargo. Cell Rep (2020) 32(2):107881. doi: 10.1016/j.celrep.2020.107881

50. Guiot J, Cambier M, Boeckx A, Henket M, Nivelles O, Gester F, et al. Macrophage-Derived Exosomes Attenuate Fibrosis in Airway Epithelial Cells Through Delivery of Antifibrotic miR-142-3p. Thorax (2020) 75 (10):870-81. doi: 10.1136/thoraxjnl-2019-214077

51. McDonald MK, Tian Y, Qureshi RA, Gormley M, Ertel A, Gao R, et al. Functional Significance of Macrophage-Derived Exosomes in Inflammation and Pain. Pain (2014) 155(8):1527-39. doi: 10.1016/j.pain.2014.04.029

52. Zhu J, Liu B, Wang Z, Wang D, Ni H, Zhang L, et al. Exosomes From Nicotine-Stimulated Macrophages Accelerate Atherosclerosis Through miR21-3p/PTEN-Mediated VSMC Migration and Proliferation. Theranostics (2019) 9(23):6901-19. doi: 10.7150/thno.37357

53. Zhang YG, Song Y, Guo XL, Miao RY, Fu YQ, Miao CF, et al. Exosomes Derived From oxLDL-Stimulated Macrophages Induce Neutrophil Extracellular Traps to Drive Atherosclerosis. Cell Cycle (2019) 18 (20):2674-84. doi: 10.1080/15384101.2019.1654797

54. Xu X, Cheng J, Luo S, Huang D, Xu J, Qian Y, et al. Deoxycholic AcidStimulated Macrophage-Derived Exosomes Promote Intestinal Metaplasia and Suppress Proliferation in Human Gastric Epithelial Cells. Eur J Pharmacol (2020) 887:173566. doi: 10.1016/j.ejphar.2020.173566
55. Chen L, Yao X, Yao H, Ji Q, Ding G, Liu X. Exosomal miR-103-3p From LPS-Activated THP-1 Macrophage Contributes to the Activation of Hepatic Stellate Cells. FASEB J (2020) 34(4):5178-92. doi: 10.1096/fj.201902307RRR

56. Hu W, Xu B, Zhang J, Kou C, Liu J, Wang Q, et al. Exosomal miR-146a-5p From Treponema Pallidum-Stimulated Macrophages Reduces Endothelial Cells Permeability and Monocyte Transendothelial Migration by Targeting JAM-C. Exp Cell Res (2020) 388(1):111823. doi: 10.1016/j.yexcr.2020.111823

57. Xiong Y, Chen L, Yan C, Zhou W, Yu T, Sun Y, et al. M2 MacrophagyDerived Exosomal miRNA-5106 Induces Bone Mesenchymal Stem Cells Towards Osteoblastic Fate by Targeting Salt-Inducible Kinase 2 and 3. J Nanobiotechnol (2020) 18(1):66. doi: 10.1186/s12951-020-00622-5

58. Zhang D, Wu Y, Li Z, Chen H, Huang S, Jian C, et al. MiR-144-5p, an Exosomal miRNA From Bone Marrow-Derived Macrophage in Type 2 Diabetes, Impairs Bone Fracture Healing via Targeting Smad1. J Nanobiotechnol (2021) 19(1):226. doi: 10.1186/s12951-021-00964-8

59. Tian F, Tang P, Sun Z, Zhang R, Zhu D, He J, et al. miR-210 in Exosomes Derived From Macrophages Under High Glucose Promotes Mouse Diabetic Obesity Pathogenesis by Suppressing NDUFA4 Expression. J Diabetes Res (2020) 2020:6894684. doi: 10.1155/2020/6894684

60. Ying X, Jin X, Zhu Y, Liang M, Chang X, Zheng L. Exosomes Released From Decidual Macrophages Deliver miR-153-3p, Which Inhibits Trophoblastic Biological Behavior in Unexplained Recurrent Spontaneous Abortion. Int Immunopharmacol (2020) 88:106981. doi: 10.1016/j.intimp.2020.106981

61. Yao MY, Zhang WH, Ma WT, Liu QH, Xing LH, Zhao GF. microRNA-328 in Exosomes Derived From M2 Macrophages Exerts a Promotive Effect on the Progression of Pulmonary Fibrosis via FAM13A in a Rat Model. Exp Mol Med (2019) 51(6):1-16. doi: 10.1038/s12276-019-0255-x

62. Qi Y, Zhu T, Zhang T, Wang X, Li W, Chen D, et al. M1 MacrophageDerived Exosomes Transfer miR-222 to Induce Bone Marrow Mesenchymal Stem Cell Apoptosis. Lab Invest (2021) 101(10):1318-26. doi: 10.1038/ s41374-021-00622-5

63. Dai Y, Wang S, Chang S, Ren D, Shali S, Li C, et al. M2 Macrophage-Derived Exosomes Carry microRNA-148a to Alleviate Myocardial Ischemia/ Reperfusion Injury via Inhibiting TXNIP and the TLR4/NF-I ${ }^{\circ} \mathrm{B} / \mathrm{NLRP} 3$ Inflammasome Signaling Pathway. J Mol Cell Cardiol (2020) 142:65-79. doi: 10.1016/j.yjmcc.2020.02.007

64. Wang Y, Qiu Z, Yuan J, Li C, Zhao R, Liu W, et al. Hypoxia-Reoxygenation Induces Macrophage Polarization and Causes the Release of Exosomal miR29a to Mediate Cardiomyocyte Pyroptosis. In Vitro Cell Dev Biol Anim (2021) 57(1):30-41. doi: 10.1007/s11626-020-00524-8

65. Liu T, Sun YC, Cheng P, Shao HG. Adipose Tissue Macrophage-Derived Exosomal miR-29a Regulates Obesity-Associated Insulin Resistance. Biochem Biophys Res Commun (2019) 515(2):352-8. doi: 10.1016/ j.bbrc.2019.05.113

66. Wang Z, Zhu H, Shi H, Zhao H, Gao R, Weng X, et al. Exosomes Derived From M1 Macrophages Aggravate Neointimal Hyperplasia Following Carotid Artery Injuries in Mice Through miR-222/CDKN1B/CDKN1C Pathway. Cell Death Dis (2019) 10(6):422. doi: 10.1038/s41419-019-1667-1

67. Long R, Gao L, Li Y, Li G, Qin P, Wei Z, et al. M2 Macrophage-Derived Exosomes Carry miR-1271-5p to Alleviate Cardiac Injury in Acute Myocardial Infarction Through Down-Regulating SOX6. Mol Immunol (2021) 136:26-35. doi: 10.1016/j.molimm.2021.05.006

68. Zhou Y, Wang X, Sun L, Zhou L, Ma TC, Song L, et al. Toll-Like Receptor 3Activated Macrophages Confer Anti-HCV Activity to Hepatocytes Through Exosomes. FASEB J (2016) 30(12):4132-40. doi: 10.1096/fj.201600696R

69. Moradi-Chaleshtori M, Bandehpour M, Soudi S, Mohammadi-Yeganeh S, Hashemi SM. In Vitro and In Vivo Evaluation of Anti-Tumoral Effect of M1 Phenotype Induction in Macrophages by miR-130 and miR-33 Containing Exosomes. Cancer Immunol Immunother (2021) 70(5):1323-39. doi: 10.1007/s00262-020-02762-x

70. Li C, Deng C, Zhou T, Hu J, Dai B, Yi F, et al. MicroRNA-370 Carried by M2 Macrophage-Derived Exosomes Alleviates Asthma Progression Through Inhibiting the FGF1/MAPK/STAT1 Axis. Int J Biol Sci (2021) 17(7):1795807. doi: $10.7150 /$ ijbs. 59715

71. Li M, Li S, Du C, Zhang Y, Li Y, Chu L, et al. Exosomes From Different Cells: Characteristics, Modifications, and Therapeutic Applications. Eur J Med Chem (2020) 207:112784. doi: 10.1016/j.ejmech.2020.112784 
72. Zhu Y, Chen X, Pan Q, Wang Y, Su S, Jiang C, et al. A Comprehensive Proteomics Analysis Reveals a Secretory Path- and Status-Dependent Signature of Exosomes Released From Tumor-Associated Macrophages. J Proteome Res (2015) 14(10):4319-31. doi: 10.1021/acs.jproteome.5b00770

73. Li X, Tang M. Exosomes Released From M2 Macrophages Transfer miR221-3p Contributed to EOC Progression Through Targeting CDKN1B. Cancer Med (2020) 9(16):5976-88. doi: 10.1002/cam4.3252

74. Liu G, Ouyang X, Sun Y, Xiao Y, You B, Gao Y, et al. The miR-92a-2-5p in Exosomes From Macrophages Increases Liver Cancer Cells Invasion via Altering the AR/PHLPP/p-AKT/ $\hat{\mathrm{I}}^{2}$-Catenin Signaling. Cell Death Differ (2020) 27(12):3258-72. doi: 10.1038/s41418-020-0575-3

75. Kadiu I, Narayanasamy P, Dash PK, Zhang W, Gendelman HE. Biochemical and Biologic Characterization of Exosomes and Microvesicles as Facilitators of HIV-1 Infection in Macrophages. J Immunol (2012) 189(2):744-54. doi: 10.4049/jimmunol.1102244

76. Mayor S, Pagano RE. Pathways of Clathrin-Independent Endocytosis. Nat Rev Mol Cell Biol (2007) 8(8):603-12. doi: 10.1038/nrm2216

77. Mashouri L, Yousefi H, Aref AR, Ahadi AM, Molaei F, Alahari SK. Exosomes: Composition, Biogenesis, and Mechanisms in Cancer Metastasis and Drug Resistance. Mol Cancer (2019) 18(1):75. doi: 10.1186/ s12943-019-0991-5

78. Shan X, Zhang C, Mai C, Hu X, Cheng N, Chen W, et al. The Biogenesis, Biological Functions, and Applications of Macrophage-Derived Exosomes. Front Mol Biosci (2021) 8:715461. doi: 10.3389/fmolb.2021.715461

79. Colombo M, Raposo G, Thery C. Biogenesis, Secretion, and Intercellular Interactions of Exosomes and Other Extracellular Vesicles. Annu Rev Cell Dev Biol (2014) 30:255-89. doi: 10.1146/annurev-cellbio-101512-122326

80. Henne WM, Stenmark H, Emr SD. Molecular Mechanisms of the Membrane Sculpting ESCRT Pathway. Cold Spring Harb Perspect Biol (2013) 5(9). doi: 10.1101/cshperspect.a016766

81. Raposo G, Stoorvogel W. Extracellular Vesicles: Exosomes, Microvesicles, and Friends. J Cell Biol (2013) 200(4):373-83. doi: 10.1083/jcb.201211138

82. Hessvik NP, Llorente A. Current Knowledge on Exosome Biogenesis and Release. Cell Mol Life Sci CMLS (2018) 75(2):193-208. doi: 10.1007/s00018017-2595-9

83. Kim YB, Ahn YH, Jung JH, Lee YJ, Lee JH, Kang JL. Programming of Macrophages by UV-Irradiated Apoptotic Cancer Cells Inhibits Cancer Progression and Lung Metastasis. Cell Mol Immunol (2019) 16(11):851-67. doi: 10.1038/s41423-019-0209-1

84. Qu Y, Franchi L, Nunez G, Dubyak GR. Nonclassical IL-1 Beta Secretion Stimulated by P2X7 Receptors is Dependent on Inflammasome Activation and Correlated With Exosome Release in Murine Macrophages. J Immunol (2007) 179(3):1913-25. doi: 10.4049/jimmunol.179.3.1913

85. Valimaki E, Cypryk W, Virkanen J, Nurmi K, Turunen PM, Eklund KK, et al. Calpain Activity Is Essential for ATP-Driven Unconventional VesicleMediated Protein Secretion and Inflammasome Activation in Human Macrophages. J Immunol (2016) 197(8):3315-25. doi: 10.4049/ jimmunol.1501840

86. Li ZG, Scott MJ, BrzÃ $\tilde{A}^{3}$ ka T, Sundd P, Li YH, Billiar TR, et al. Lung Epithelial Cell-Derived IL-25 Negatively Regulates LPS-Induced Exosome Release From Macrophages. Mil Med Res (2018) 5(1):24. doi: 10.1186/ s40779-018-0173-6

87. Stein M, Keshav S, Harris N, Gordon S. Interleukin 4 Potently Enhances Murine Macrophage Mannose Receptor Activity: A Marker of Alternative Immunologic Macrophage Activation. J Exp Med (1992) 176(1):287-92. doi: $10.1084 /$ jem.176.1.287

88. Murray PJ, Wynn TA. Obstacles and Opportunities for Understanding Macrophage Polarization. J Leukoc Biol (2011) 89(4):557-63. doi: 10.1189/ jlb.0710409

89. Mantovani A, Sica A, Sozzani S, Allavena P, Vecchi A, Locati M. The Chemokine System in Diverse Forms of Macrophage Activation and Polarization. Trends Immunol (2004) 25(12):677-86. doi: 10.1016/ j.it.2004.09.015

90. Sica A, Mantovani A. Macrophage Plasticity and Polarization: In Vivo Veritas. J Clin Invest (2012) 122(3):787-95. doi: 10.1172/jci59643

91. Murray PJ, Allen JE, Biswas SK, Fisher EA, Gilroy DW, Goerdt S, et al. Macrophage Activation and Polarization: Nomenclature and Experimental
Guidelines. Immunity (2014) 41(1):14-20. doi: 10.1016/ j.immuni.2014.06.008

92. Sica A, Erreni M, Allavena P, Porta C. Macrophage Polarization in Pathology. Cell Mol Life Sci (2015) 72(21):4111-26. doi: 10.1007/s00018015-1995-y

93. Bashir S, Sharma Y, Elahi A, Khan F. Macrophage Polarization: The Link Between Inflammation and Related Diseases. Inflammation Res (2016) 65 (1):1-11. doi: 10.1007/s00011-015-0874-1

94. Jetten N, Verbruggen S, Gijbels MJ, Post MJ, De Winther MP, Donners MM. Anti-Inflammatory M2, But Not Pro-Inflammatory M1 Macrophages Promote Angiogenesis. Vivo Angiogenesis (2014) 17(1):109-18. doi: 10.1007/s10456-013-9381-6

95. Wang N, Liang H, Zen K. Molecular Mechanisms That Influence the Macrophage M1-M2 Polarization Balance. Front Immunol (2014) 5:614. doi: 10.3389/fimmu.2014.00614

96. Porta C, Riboldi E, Ippolito A, Sica A. Molecular and Epigenetic Basis of Macrophage Polarized Activation. Semin Immunol (2015) 27(4):237-48. doi: 10.1016/j.smim.2015.10.003

97. Funes SC, Rios M, Escobar-Vera J, Kalergis AM. Implications of Macrophage Polarization in Autoimmunity. Immunology (2018) 154 (2):186-95. doi: 10.1111/imm.12910

98. Wang C, Zhang C, Liu L, A X, Chen B, Li Y, et al. Macrophage-Derived Mir155-Containing Exosomes Suppress Fibroblast Proliferation and Promote Fibroblast Inflammation During Cardiac Injury. Mol Ther (2017) 25(1):192204. doi: 10.1016/j.ymthe.2016.09.001

99. Yang M, Chen J, Su F, Yu B, Su F, Lin L, et al. Microvesicles Secreted by Macrophages Shuttle Invasion-Potentiating microRNAs Into Breast Cancer Cells. Mol Cancer (2011) 10:117. doi: 10.1186/1476-4598-10-117

100. Kang M, Huang CC, Lu Y, Shirazi S, Gajendrareddy P, Ravindran S, et al. Bone Regeneration is Mediated by Macrophage Extracellular Vesicles. Bone (2020) 141:115627. doi: 10.1016/j.bone.2020.115627

101. Reuter S, Gupta SC, Chaturvedi MM, Aggarwal BB. Oxidative Stress, Inflammation, and Cancer: How are They Linked? Free Radic Biol Med (2010) 49(11):1603-16. doi: 10.1016/j.freeradbiomed.2010.09.006

102. Kunnumakkara AB, Sailo BL, Banik K, Harsha C, Prasad S, Gupta SC, et al. Chronic Diseases, Inflammation, and Spices: How are They Linked? J Transl Med (2018) 16(1):14. doi: 10.1186/s12967-018-1381-2

103. Tabas I, Glass CK. Anti-Inflammatory Therapy in Chronic Disease: Challenges and Opportunities. Science (2013) 339(6116):166-72. doi: $10.1126 /$ science. 1230720

104. Hwang I. Cell-Cell Communication via Extracellular Membrane Vesicles and its Role in the Immune Response. Mol Cells (2013) 36(2):105-11. doi: 10.1007/s10059-013-0154-2

105. Baig MS, Roy A, Rajpoot S, Liu D, Savai R, Banerjee S, et al. Tumor-Derived Exosomes in the Regulation of Macrophage Polarization. Inflammation Res (2020) 69(5):435-51. doi: 10.1007/s00011-020-01318-0

106. Duan S, Yu S, Yuan T, Yao S, Zhang L. Exogenous Let-7a-5p Induces A549 Lung Cancer Cell Death Through BCL2L1-Mediated PI3Kî $\hat{\mathrm{I}}^{3}$ Signaling Pathway. Front Oncol (2019) 9:808. doi: 10.3389/fonc.2019.00808

107. Lan J, Sun L, Xu F, Liu L, Hu F, Song D, et al. M2 Macrophage-Derived Exosomes Promote Cell Migration and Invasion in Colon Cancer. Cancer Res (2019) 79(1):146-58. doi: 10.1158/0008-5472.can-18-0014

108. Moore KJ, Sheedy FJ, Fisher EA. Macrophages in Atherosclerosis: A Dynamic Balance. Nat Rev Immunol (2013) 13(10):709-21. doi: 10.1038/ nri3520

109. Koelwyn GJ, Corr EM, Erbay E, Moore KJ. Regulation of Macrophage Immunometabolism in Atherosclerosis. Nat Immunol (2018) 19(6):526-37. doi: 10.1038/s41590-018-0113-3

110. Tabas I, Bornfeldt KE. Macrophage Phenotype and Function in Different Stages of Atherosclerosis. Circ Res (2016) 118(4):653-67. doi: 10.1161/ circresaha.115.306256

111. Moore KJ, Tabas I. Macrophages in the Pathogenesis of Atherosclerosis. Cell (2011) 145(3):341-55. doi: 10.1016/j.cell.2011.04.005

112. Llodr $\tilde{A}_{i}$ J, Angeli V, Liu J, Trogan E, Fisher EA, Randolph GJ. Emigration of Monocyte-Derived Cells From Atherosclerotic Lesions Characterizes Regressive, But Not Progressive, Plaques. Proc Natl Acad Sci U.S.A. (2004) 101(32):11779-84. doi: 10.1073/pnas.0403259101 
113. Chistiakov DA, Orekhov AN, Bobryshev YV. Extracellular Vesicles and Atherosclerotic Disease. Cell Mol Life Sci (2015) 72(14):2697-708. doi: 10.1007/s00018-015-1906-2

114. Hoyer FF, Giesen MK, Nunes FranÃßa C, LÃ $1 / 4$ tjohann D, Nickenig G, Werner N. Monocytic Microparticles Promote Atherogenesis by Modulating Inflammatory Cells in Mice. J Cell Mol Med (2012) 16(11):2777-88. doi: 10.1111/j.1582-4934.2012.01595.x

115. Ismail N, Wang Y, Dakhlallah D, Moldovan L, Agarwal K, Batte K, et al. Macrophage Microvesicles Induce Macrophage Differentiation and miR-223 Transfer. Blood (2013) 121(6):984-95. doi: 10.1182/blood-2011-08-374793

116. Nguyen MA, Karunakaran D, Geoffrion M, Cheng HS, Tandoc K, Perisic Matic L, et al. Extracellular Vesicles Secreted by Atherogenic Macrophages Transfer MicroRNA to Inhibit Cell Migration. Arterioscler Thromb Vasc Biol (2018) 38(1):49-63. doi: 10.1161/atvbaha.117.309795

117. Van den Bossche J, Baardman J, Otto NA, van der Velden S, Neele AE, van den Berg SM, et al. Mitochondrial Dysfunction Prevents Repolarization of Inflammatory Macrophages. Cell Rep (2016) 17(3):684-96. doi: 10.1016/ j.celrep.2016.09.008

118. van der Vorst EPC, Weber C. Novel Features of Monocytes and Macrophages in Cardiovascular Biology and Disease. Arterioscler Thromb Vasc Biol (2019) 39(2):e30-7. doi: 10.1161/atvbaha.118.312002

119. Jablonski KA, Gaudet AD, Amici SA, Popovich PG, Guerau-de-Arellano M. Control of the Inflammatory Macrophage Transcriptional Signature by miR155. PloS One (2016) 11(7):e0159724. doi: 10.1371/journal.pone.0159724

120. Richards J, Gabunia K, Kelemen SE, Kako F, Choi ET, Autieri MV. Interleukin-19 Increases Angiogenesis in Ischemic Hind Limbs by Direct Effects on Both Endothelial Cells and Macrophage Polarization. J Mol Cell Cardiol (2015) 79:21-31. doi: 10.1016/j.yjmcc.2014.11.002

121. Zhao T, Wu W, Sui L, Huang Q, Nan Y, Liu J, et al. Reactive Oxygen SpeciesBased Nanomaterials for the Treatment of Myocardial Ischemia Reperfusion Injuries. Bioact Mater (2022) 7:47-72. doi: 10.1016/j.bioactmat.2021.06.006

122. Johnson AM, Olefsky JM. The Origins and Drivers of Insulin Resistance. Cell (2013) 152(4):673-84. doi: 10.1016/j.cell.2013.01.041

123. Ehses JA, BÃni-Schnetzler M, Faulenbach M, Donath MY. Macrophages, Cytokines and Beta-Cell Death in Type 2 Diabetes. Biochem Soc Trans (2008) 36(Pt 3):340-2. doi: 10.1042/bst0360340

124. Eguchi K, Manabe I. Macrophages and Islet Inflammation in Type 2 Diabetes. Diabetes Obes Metab (2013) 15 Suppl;3:152-8. doi: 10.1111/ dom. 12168

125. Gregor MF, Hotamisligil GS. Inflammatory Mechanisms in Obesity. Annu Rev Immunol (2011) 29:415-45. doi: 10.1146/annurev-immunol-031210-101322

126. Lumeng CN, Deyoung SM, Bodzin JL, Saltiel AR. Increased Inflammatory Properties of Adipose Tissue Macrophages Recruited During Diet-Induced Obesity. Diabetes (2007) 56(1):16-23. doi: 10.2337/db06-1076

127. Zeyda M, Stulnig TM. Adipose Tissue Macrophages. Immunol Lett (2007) 112(2):61-7. doi: 10.1016/j.imlet.2007.07.003

128. Ying W, Riopel M, Bandyopadhyay G, Dong Y, Birmingham A, Seo JB, et al. Adipose Tissue Macrophage-Derived Exosomal miRNAs Can Modulate InÂ Vivo and InÂ Vitro Insulin Sensitivity. Cell (2017) 171(2):372-384.e312. doi: 10.1016/j.cell.2017.08.035

129. Qian B, Yang Y, Tang N, Wang J, Sun P, Yang N, et al. M1 MacrophageDerived Exosomes Impair Beta Cell Insulin Secretion via miR-212-5p by Targeting SIRT2 and Inhibiting Akt/GSK-3î̀ $/ / \mathrm{I}^{2}$-Catenin Pathway in Mice. Diabetologia (2021) 64(9):2037-51. doi: 10.1007/s00125-021-05489-1

130. Wang W, Yan X, Lin Y, Ge H, Tan Q. Wnt7a Promotes Wound Healing by Regulation of Angiogenesis and Inflammation: Issues on Diabetes and Obesity. J Dermatol Sci (2018) S0923-1811(18)30103-30108. doi: 10.1016/ j.jdermsci.2018.02.007

131. Li M, Wang T, Tian H, Wei G, Zhao L, Shi Y. Macrophage-Derived Exosomes Accelerate Wound Healing Through Their Anti-Inflammation Effects in a Diabetic Rat Model. Artif Cells Nanomed Biotechnol (2019) 47 (1):3793-803. doi: 10.1080/21691401.2019.1669617

132. Kim H, Wang SY, Kwak G, Yang Y, Kwon IC, Kim SH. Exosome-Guided Phenotypic Switch of M1 to M2 Macrophages for Cutaneous Wound Healing. Advanced Sci (Weinheim Baden-Wurttemberg Germany) (2019) 6 (20):1900513-1900513. doi: 10.1002/advs.201900513

133. Huang H, Liu H, Tang J, Xu W, Gan H, Fan Q, et al. M2 MacrophageDerived Exosomal miR-25-3p Improves High Glucose-Induced Podocytes
Injury Through Activation Autophagy via Inhibiting DUSP1 Expression. IUBMB Life (2020) 72(12):2651-62. doi: 10.1002/iub.2393

134. Zhu M, Sun X, Qi X, Xia L, Wu Y. Exosomes From High Glucose-Treated Macrophages Activate Macrophages Andinduce Inflammatory Responses via NF-Iิ'B Signaling Pathway In Vitro and In Vivo. Int Immunopharmacol (2020) 84:106551. doi: 10.1016/j.intimp.2020.106551

135. Torre LA, Siegel RL, Ward EM, Jemal A. Global Cancer Incidence and Mortality Rates and Trends-An Update. Cancer Epidemiol Biomarkers Prev (2016) 25(1):16-27. doi: 10.1158/1055-9965.epi-15-0578

136. Colotta F, Allavena P, Sica A, Garlanda C, Mantovani A. Cancer-Related Inflammation, the Seventh Hallmark of Cancer: Links to Genetic Instability. Carcinogenesis (2009) 30(7):1073-81. doi: 10.1093/carcin/bgp127

137. Paget S. The Distribution of Secondary Growths in Cancer of the Breast. 1889. Cancer Metastasis Rev (1989) 8(2):98-101.

138. Williams CB, Yeh ES, Soloff AC. Tumor-Associated Macrophages: Unwitting Accomplices in Breast Cancer Malignancy. NPJ Breast Cancer (2016) 2:15025-. doi: 10.1038/npjbcancer.2015.25

139. Salmaninejad A, Valilou SF, Soltani A, Ahmadi S, Abarghan YJ, Rosengren RJ, et al. Tumor-Associated Macrophages: Role in Cancer Development and Therapeutic Implications. Cell Oncol (Dordr) (2019) 42(5):591-608. doi: 10.1007/s13402-019-00453-z

140. Guerriero JL. Macrophages: The Road Less Traveled, Changing Anticancer Therapy. Trends Mol Med (2018) 24(5):472-89. doi: 10.1016/ j.molmed.2018.03.006

141. Vitale I, Manic G, Coussens LM, Kroemer G, Galluzzi L. Macrophages and Metabolism in the Tumor Microenvironment. Cell Metab (2019) 30(1):3650. doi: 10.1016/j.cmet.2019.06.001

142. van der Pol E, BÃing AN, Harrison P, Sturk A, Nieuwland R. Classification, Functions, and Clinical Relevance of Extracellular Vesicles. Pharmacol Rev (2012) 64(3):676-705. doi: 10.1124/pr.112.005983

143. Steinbichler TB, DudÃ $\tilde{i}_{i}$ J, Riechelmann H, Skvortsova II. The Role of Exosomes in Cancer Metastasis. Semin Cancer Biol (2017) 44:170-81. doi: 10.1016/j.semcancer.2017.02.006

144. Zheng P, Luo Q, Wang W, Li J, Wang T, Wang P, et al. Tumor-Associated Macrophages-Derived Exosomes Promote the Migration of Gastric Cancer Cells by Transfer of Functional Apolipoprotein E. Cell Death Dis (2018) 9 (4):434. doi: 10.1038/s41419-018-0465-5

145. Wang Y, Jia L, Xie Y, Cai Z, Liu Z, Shen J, et al. Involvement of MacrophageDerived Exosomes in Abdominal Aortic Aneurysms Development. Atherosclerosis (2019) 289:64-72. doi: 10.1016/j.atherosclerosis.2019.08.016

146. Zheng P, Chen L, Yuan X, Luo Q, Liu Y, Xie G, et al. Exosomal Transfer of Tumor-Associated Macrophage-Derived miR-21 Confers Cisplatin Resistance in Gastric Cancer Cells. J Exp Clin Cancer Res (2017) 36(1):53. doi: 10.1186/s13046-017-0528-y

147. Yin Z, Ma T, Huang B, Lin L, Zhou Y, Yan J, et al. Macrophage-Derived Exosomal microRNA-501-3p Promotes Progression of Pancreatic Ductal Adenocarcinoma Through the TGFBR3-Mediated TGF-Î̃² Signaling Pathway. J Exp Clin Cancer Res (2019) 38(1):310. doi: 10.1186/s13046-019-1313-x

148. Guan H, Peng R, Fang F, Mao L, Chen Z, Yang S, et al. Tumor-Associated Macrophages Promote Prostate Cancer Progression via Exosome-Mediated miR-95 Transfer. J Cell Physiol (2020) 235(12):9729-42. doi: 10.1002/ jcp. 29784

149. Zhu X, Shen H, Yin X, Yang M, Wei H, Chen Q, et al. Macrophages Derived Exosomes Deliver miR-223 to Epithelial Ovarian Cancer Cells to Elicit a Chemoresistant Phenotype. J Exp Clin Cancer Res (2019) 38(1):81. doi: 10.1186/s13046-019-1095-1

150. Hu Y, Li D, Wu A, Qiu X, Di W, Huang L, et al. TWEAK-Stimulated Macrophages Inhibit Metastasis of Epithelial Ovarian Cancer via Exosomal Shuttling of microRNA. Cancer Lett (2017) 393:60-7. doi: 10.1016/ j.canlet.2017.02.009

151. Wu Q, Wu X, Ying X, Zhu Q, Wang X, Jiang L, et al. Suppression of Endothelial Cell Migration by Tumor Associated Macrophage-Derived Exosomes is Reversed by Epithelial Ovarian Cancer Exosomal lncRNA. Cancer Cell Int (2017) 17:62. doi: 10.1186/s12935-017-0430-x

152. Zhou J, Li X, Wu X, Zhang T, Zhu Q, Wang X, et al. Exosomes Released From Tumor-Associated Macrophages Transfer miRNAs That Induce a Treg/Th17 Cell Imbalance in Epithelial Ovarian Cancer. Cancer Immunol Res (2018) 6(12):1578-92. doi: 10.1158/2326-6066.cir-17-0479 
153. Aucher A, Rudnicka D, Davis DM. MicroRNAs Transfer From Human Macrophages to Hepato-Carcinoma Cells and Inhibit Proliferation. J Immunol (2013) 191(12):6250-60. doi: 10.4049/jimmunol.1301728

154. Wang Y, Wang B, Xiao S, Li Y, Chen Q. miR-125a/B Inhibits TumorAssociated Macrophages Mediated in Cancer Stem Cells of Hepatocellular Carcinoma by Targeting CD90. J Cell Biochem (2019) 120(3):3046-55. doi: $10.1002 /$ jcb. 27436

155. Liu G, Yin L, Ouyang X, Zeng K, Xiao Y, Li Y. M2 Macrophages Promote HCC Cells Invasion and Migration via miR-149-5p/MMP9 Signaling. J Cancer (2020) 11(5):1277-87. doi: 10.7150/jca.35444

156. Binenbaum Y, Fridman E, Yaari Z, Milman N, Schroeder A, Ben David G, et al. Transfer of miRNA in Macrophage-Derived Exosomes Induces Drug Resistance in Pancreatic Adenocarcinoma. Cancer Res (2018) 78(18):528799. doi: 10.1158/0008-5472.can-18-0124

157. Challagundla KB, Wise PM, Neviani P, Chava H, Murtadha M, Xu T, et al. Exosome-Mediated Transfer of microRNAs Within the Tumor Microenvironment and Neuroblastoma Resistance to Chemotherapy. J Natl Cancer Inst (2015) 107(7):djv135. doi: 10.1093/jnci/djv135

158. Yang F, Wang T, Du P, Fan H, Dong X, Guo H. M2 Bone Marrow-Derived Macrophage-Derived Exosomes Shuffle microRNA-21 to Accelerate Immune Escape of Glioma by Modulating PEG3. Cancer Cell Int (2020) 20:93. doi: $10.1186 /$ s12935-020-1163-9

159. Wu ATH, Srivastava P, Yadav VK, Tzeng DTW, Iamsaard S, Su EC, et al. Ovatodiolide, Isolated From Anisomeles Indica, Suppresses Bladder Carcinogenesis Through Suppression of $\mathrm{mTOR} / \hat{\mathrm{I}}^{2}$-Catenin/CDK6 and Exosomal miR-21 Derived From M2 Tumor-Associated Macrophages. Toxicol Appl Pharmacol (2020) 401:115109. doi: 10.1016/j.taap.2020.115109

160. Mi X, Xu R, Hong S, Xu T, Zhang W, Liu M. M2 Macrophage-Derived Exosomal lncRNA AFAP1-AS1 and MicroRNA-26a Affect Cell Migration and Metastasis in Esophageal Cancer. Mol Ther Nucleic Acids (2020) 22:77990. doi: 10.1016/j.omtn.2020.09.035

161. Simpson RJ, Lim JW, Moritz RL, Mathivanan S. Exosomes: Proteomic Insights and Diagnostic Potential. Expert Rev Proteomics (2009) 6(3):26783. doi: $10.1586 /$ epr.09.17

162. Fontana S, Saieva L, Taverna S, Alessandro R. Contribution of Proteomics to Understanding the Role of Tumor-Derived Exosomes in Cancer Progression: State of the Art and New Perspectives. Proteomics (2013) 13(10-11):1581-94. doi: $10.1002 /$ pmic. 201200398

163. Cianciaruso C, Beltraminelli T, Duval F, Nassiri S, Hamelin R, Mozes A, et al. Molecular Profiling and Functional Analysis of Macrophage-Derived Tumor Extracellular Vesicles. Cell Rep (2019) 27(10):3062-3080.e3011. doi: 10.1016/ j.celrep.2019.05.008

164. Sharma A, Johnson A. Exosome DNA: Critical Regulator of Tumor Immunity and a Diagnostic Biomarker. J Cell Physiol (2020) 235(3):192132. doi: $10.1002 /$ jcp. 29153

165. Tomita R, Sasabe E, Tomomura A, Yamamoto T. Macrophageâ€'derived Exosomes Attenuate the Susceptibility of Oral Squamous Cell Carcinoma Cells to Chemotherapeutic Drugs Through the AKT/Gskâ $\epsilon^{\prime} \hat{I}^{2}$ Pathway. Oncol Rep (2020) 44(5):1905-16. doi: 10.3892/or.2020.7748

166. Chen F, Chen J, Yang L, Liu J, Zhang X, Zhang Y, et al. Extracellular

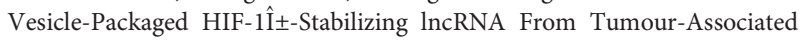
Macrophages Regulates Aerobic Glycolysis of Breast Cancer Cells. Nat Cell Biol (2019) 21(4):498-510. doi: 10.1038/s41556-019-0299-0

167. Wilson MS, Wynn TA. Pulmonary Fibrosis: Pathogenesis, Etiology and Regulation. Mucosal Immunol (2009) 2(2):103-21. doi: 10.1038/ mi. 2008.85

168. Tan S, Chen S. Macrophage Autophagy and Silicosis: Current Perspective and Latest Insights. Int J Mol Sci (2021) 22(1):453. doi: 10.3390/ijms22010453

169. Ye C, Li H, Bao M, Zhuo R, Jiang G, Wang W. Alveolar Macrophage Derived Exosomes Modulate Severity and Outcome of Acute Lung Injury. Aging (Albany NY) (2020) 12(7):6120-8. doi: 10.18632/aging.103010

170. Alwarith J, Kahleova H, Crosby L, Brooks A, Brandon L, Levin SM, et al. The Role of Nutrition in Asthma Prevention and Treatment. Nutr Rev (2020) 78 (11):928-38. doi: 10.1093/nutrit/nuaa005

171. Busada JT, Ramamoorthy S, Cain DW, Xu X, Cook DN, Cidlowski JA. Endogenous Glucocorticoids Prevent Gastric Metaplasia by Suppressing Spontaneous Inflammation. J Clin Invest (2019) 129(3):1345-58. doi: $10.1172 /$ jci123233
172. Xu X, Cheng J, Luo S, Gong X, Huang D, Xu J, et al. Deoxycholic AcidStimulated Macrophage-Derived Exosomes Promote Spasmolytic Polypeptide-Expressing Metaplasia in the Stomach. Biochem Biophys Res Commun (2020) 524(3):649-55. doi: 10.1016/j.bbrc.2020.01.159

173. Di Sabatino A, Lenti MV, Giuffrida P, Vanoli A, Corazza GR. New Insights Into Immune Mechanisms Underlying Autoimmune Diseases of the Gastrointestinal Tract. Autoimmun Rev (2015) 14(12):1161-9. doi: 10.1016/j.autrev.2015.08.004

174. Zheng Y, He R, Wang P, Shi Y, Zhao L, Liang J. Exosomes From LPSStimulated Macrophages Induce Neuroprotection and Functional Improvement After Ischemic Stroke by Modulating Microglial Polarization. Biomater Sci (2019) 7(5):2037-49. doi: 10.1039/c8bm01449c

175. Choo YW, Kang M, Kim HY, Han J, Kang S, Lee JR, et al. M1 MacrophageDerived Nanovesicles Potentiate the Anticancer Efficacy of Immune Checkpoint Inhibitors. ACS Nano (2018) 12(9):8977-93. doi: 10.1021/ acsnano. $8 \mathrm{~b} 02446$

176. Kanchanapally R, Deshmukh SK, Chavva SR, Tyagi N, Srivastava SK, Patel GK, et al. Drug-Loaded Exosomal Preparations From Different Cell Types Exhibit Distinctive Loading Capability, Yield, and Antitumor Efficacies: A Comparative Analysis. Int J Nanomed (2019) 14:531-41. doi: 10.2147/ ijn.s191313

177. Zhang X, Liu L, Tang M, Li H, Guo X, Yang X. The Effects of Umbilical Cord-Derived Macrophage Exosomes Loaded With Cisplatin on the Growth and Drug Resistance of Ovarian Cancer Cells. Drug Dev Ind Pharm (2020) 46 (7):1150-62. doi: 10.1080/03639045.2020.1776320

178. Giri PK, Schorey JS. Exosomes Derived From M. Bovis BCG Infected Macrophages Activate Antigen-Specific CD4+ and CD8+ T Cells In Vitro and In Vivo. PloS One (2008) 3(6):e2461. doi: 10.1371/journal.pone.0002461

179. Cheng L, Wang Y, Huang L. Exosomes From M1-Polarized Macrophages Potentiate the Cancer Vaccine by Creating a Pro-Inflammatory Microenvironment in the Lymph Node. Mol Ther (2017) 25(7):1665-75. doi: 10.1016/j.ymthe.2017.02.007

180. Haney MJ, Klyachko NL, Zhao Y, Gupta R, Plotnikova EG, He Z, et al. Exosomes as Drug Delivery Vehicles for Parkinson's Disease Therapy. J Control Release (2015) 207:18-30. doi: 10.1016/j.jconrel.2015.03.033

181. Huang Z, Guo L, Huang L, Shi Y, Liang J, Zhao L. Baicalin-Loaded Macrophage-Derived Exosomes Ameliorate Ischemic Brain Injury via the Antioxidative Pathway. Mater Sci Eng C Mater Biol Appl (2021) 126:112123. doi: 10.1016/j.msec.2021.112123

182. Kim MS, Haney MJ, Zhao Y, Mahajan V, Deygen I, Klyachko NL, et al. Development of Exosome-Encapsulated Paclitaxel to Overcome MDR in Cancer Cells. Nanomedicine (2016) 12(3):655-64. doi: 10.1016/ j.nano.2015.10.012

183. Gao ZS, Zhang CJ, Xia N, Tian H, Li DY, Lin JQ, et al. Berberine-Loaded M2 Macrophage-Derived Exosomes for Spinal Cord Injury Therapy. Acta Biomater (2021) 126:211-23. doi: 10.1016/j.actbio.2021.03.018

184. Kim MS, Haney MJ, Zhao Y, Yuan D, Deygen I, Klyachko NL, et al. Engineering Macrophage-Derived Exosomes for Targeted Paclitaxel Delivery to Pulmonary Metastases: In Vitro and In Vivo Evaluations. Nanomed: Nanotechnol Biol Med (2018) 14(1):195-204. doi: 10.1016/ j.nano.2017.09.011

185. Nie W, Wu G, Zhang J, Huang LL, Ding J, Jiang A, et al. Responsive Exosome Nano-Bioconjugates for Synergistic Cancer Therapy. Angew Chem Int Ed Engl (2020) 59(5):2018-22. doi: 10.1002/anie.201912524

186. Huo Q, Shi Y, Qi Y, Huang L, Sui H, Zhao L. Biomimetic Silibinin-Loaded Macrophage-Derived Exosomes Induce Dual Inhibition of $\mathrm{A}^{2}$ Aggregation and Astrocyte Activation to Alleviate Cognitive Impairment in a Model of Alzheimer's Disease. Mater Sci Eng C Mater Biol Appl (2021) 129:112365. doi: $10.1016 /$ j.msec.2021.112365

187. Gong C, Tian J, Wang Z, Gao Y, Wu X, Ding X, et al. Functional ExosomeMediated Co-Delivery of Doxorubicin and Hydrophobically Modified microRNA 159 for Triple-Negative Breast Cancer Therapy. J Nanobiotechnol (2019) 17(1):93. doi: 10.1186/s12951-019-0526-7

188. Li S, Wu Y, Ding F, Yang J, Li J, Gao X, et al. Engineering MacrophageDerived Exosomes for Targeted Chemotherapy of Triple-Negative Breast Cancer. Nanoscale (2020) 12(19):10854-62. doi: 10.1039/d0nr00523a

189. Wu G, Zhang J, Zhao Q, Zhuang W, Ding J, Zhang C, et al. Molecularly Engineered Macrophage-Derived Exosomes With Inflammation Tropism 
and Intrinsic Heme Biosynthesis for Atherosclerosis Treatment. Angew Chem Int Ed Engl (2020) 59(10):4068-74. doi: 10.1002/anie.201913700

190. Wang P, Wang H, Huang Q, Peng C, Yao L, Chen H, et al. Exosomes From M1-Polarized Macrophages Enhance Paclitaxel Antitumor Activity by Activating Macrophages-Mediated Inflammation. Theranostics (2019) 9 (6):1714-27. doi: 10.7150/thno.30716

191. Lai RC, Yeo RW, Tan KH, Lim SK. Exosomes for Drug Delivery - a Novel Application for the Mesenchymal Stem Cell. Biotechnol Adv (2013) 31 (5):543-51. doi: 10.1016/j.biotechadv.2012.08.008

192. Tran TH, Mattheolabakis G, Aldawsari H, Amiji M. Exosomes as Nanocarriers for Immunotherapy of Cancer and Inflammatory Diseases. Clin Immunol (2015) 160(1):46-58. doi: 10.1016/j.clim.2015.03.021

193. Pardridge WM. Drug Transport Across the Blood-Brain Barrier. J Cereb Blood Flow Metab (2012) 32(11):1959-72. doi: 10.1038/jcbfm.2012.126

194. Luan X, Sansanaphongpricha K, Myers I, Chen H, Yuan H, Sun D. Engineering Exosomes as Refined Biological Nanoplatforms for Drug Delivery. Acta Pharmacol Sin (2017) 38(6):754-63. doi: 10.1038/aps.2017.12

195. Zhao X, Zhao Y, Sun X, Xing Y, Wang X, Yang Q. Immunomodulation of MSCs and MSC-Derived Extracellular Vesicles in Osteoarthritis. Front Bioeng Biotechnol (2020) 8:575057. doi: 10.3389/fbioe.2020.575057

196. Jang SC, Kim OY, Yoon CM, Choi DS, Roh TY, Park J, et al. Bioinspired Exosome-Mimetic Nanovesicles for Targeted Delivery of Chemotherapeutics to Malignant Tumors. ACS Nano (2013) 7(9):7698-710. doi: 10.1021/nn402232g
197. Latvall J, Hill AF, Hochberg F, BuzÃ $j$ s EI, Di Vizio D, Gardiner C, et al. Minimal Experimental Requirements for Definition of Extracellular Vesicles and Their Functions: A Position Statement From the International Society for Extracellular Vesicles. J Extracell Vesicles (2014) 3:26913. doi: 10.3402/ jev.v3.26913

Conflict of Interest: The authors declare that the research was conducted in the absence of any commercial or financial relationships that could be construed as a potential conflict of interest.

Publisher's Note: All claims expressed in this article are solely those of the authors and do not necessarily represent those of their affiliated organizations, or those of the publisher, the editors and the reviewers. Any product that may be evaluated in this article, or claim that may be made by its manufacturer, is not guaranteed or endorsed by the publisher.

Copyright (c) 2021 Xing, Sun, Dou, Wang, Zhao, Yang and Zhao. This is an openaccess article distributed under the terms of the Creative Commons Attribution License (CC BY). The use, distribution or reproduction in other forums is permitted, provided the original author(s) and the copyright owner(s) are credited and that the original publication in this journal is cited, in accordance with accepted academic practice. No use, distribution or reproduction is permitted which does not comply with these terms. 